\title{
Induction of Hypertrophy in Cultured Proximal Tubule Cells by Extracellular $\mathrm{NH}_{4} \mathrm{Cl}$
}

\author{
K. Golchini, J. Norman, R. Bohman, and I. Kurtz \\ Division of Nephrology, Department of Medicine, University of California Los Angeles School of Medicine, Los Angeles, California 90024
}

\begin{abstract}
Ammonia production increases in several models of renal hypertrophy in vivo. The present study was designed to determine whether ammonia can directly modulate the growth of renal cells in the absence of a change in extracellular acidity. In serum-free media $\mathrm{NH}_{4} \mathrm{Cl}(0-20 \mathrm{mM})$ caused JTC cells and a primary culture of rabbit proximal tubule cells to hypertrophy (increase in cell protein content) in a dose-dependent fashion without a change in DNA synthesis. Studies in JTC cells revealed that the cell protein content increased as a result of both an increase in protein synthesis and a decrease in protein degradation. Total cell RNA content and ribosome number increased after $\mathrm{NH}_{4} \mathrm{Cl}$ exposure and the cell content of the lysosomal enzymes cathepsin $B$ and $L$ decreased. Inhibition of the $\mathrm{Na}^{+} / \mathrm{H}^{+}$antiporter with amiloride did not prevent the hypertrophic response induced by $\mathrm{NH}_{4} \mathrm{Cl}$. The results indicate that ammonia is an important modulator of renal cell growth and that hypertrophy can occur in the absence of functioning $\mathrm{Na}^{+} / \mathrm{H}^{+}$antiport activity.
\end{abstract}

\section{Introduction}

Renal hypertrophy occurs in such diverse clinical states as $(a)$ protein loading, $(b) \mathrm{NH}_{4} \mathrm{Cl}$-induced metabolic acidosis, $(c)$ hypokalemia, $(d)$ diabetes mellitus (type 1$)$, and $(e)$ reduction of renal mass (1). However, the signaling events that cause the kidney to hypertrophy in these disorders are presently unknown. An adaptation of the renal tubule that characterizes several models of renal hypertrophy is an increase in the activity of the brush border $\mathrm{Na}^{+} / \mathrm{H}^{+}$exchanger (2-8). However, there are no studies that have addressed the question of whether renal hypertrophy can occur in the absence of functioning $\mathrm{Na}^{+} / \mathrm{H}^{+}$antiport activity.

It has not been previously recognized that in addition to an increase in $\mathrm{Na}^{+} / \mathrm{H}^{+}$antiport activity many models of renal hypertrophy, i.e., protein loading, $\mathrm{NH}_{4} \mathrm{Cl}$ loading, hypokalemia, diabetes mellitus (type 1), and a reduction in renal mass have in common an increase in ammonia production and/or excretion per nephron (2, 9-17). In addition, calcium restriction and deoxycorticosterone acetate administration cause renal hypertrophy and are associated with an increase in renal ammonia production and/or excretion (18-22). The finding that there is increased ammonia production and/or excretion

Address correspondence to Dr. Ira Kurtz, University of California, Los Angeles, Division of Nephrology, Department of Medicine, UCLA School of Medicine, Los Angeles, CA 90024.

Received for publication 3 January 1989 and in revised form 3 August 1989.

J. Clin. Invest.

(C) The American Society for Clinical Investigation, Inc.

$0021-9738 / 89 / 12 / 1767 / 13 \quad \$ 2.00$

Volume 84, December 1989, 1767-1779 in models of renal hypertrophy is intriguing given recent evidence in nonrenal cells that suggests that ammonia may be an important modulator of cell growth. Specifically, extracellular $\mathrm{NH}_{4} \mathrm{Cl}$ has been recently shown to cause an increase in cell protein content in cultured astrocytes (23) and human gingival fibroblasts (24). In addition, several studies have documented that extracellular $\mathrm{NH}_{4} \mathrm{Cl}$ decreases the rate of protein degradation in cultured rat hepatocytes (25), rat fibroblasts (26), and mouse macrophages (27). Other studies have shown that $(a)$ the ammonium ion modulates ribosomal RNA synthesis during Xenopus laevis embryogenesis (28), (b) ammonia is secreted during slime mold development and affects cAMP content (29), (c) ammonia affects spore cell differentiation and modulates stalk cell formation (30), and $(d)$ ammonia exposure results in the stimulation of protein and DNA synthesis in sea urchin eggs (31). The results of these studies suggest that ammonia, either alone or in concert with other growth factors, may play a pivotal role as a growth modulator in renal cells.

Lotspeich $(9,32)$ and Halliburton (33) demonstrated that rats administered $\mathrm{NH}_{4} \mathrm{Cl}$ intravenously developed acidemia and renal hypertrophy. Systemic acidemia resulted from the hepatic conversion of ammonium to urea, a process that consumes bicarbonate and prevents blood ammonia levels from increasing above normal. Animals administered ammonium citrate failed to develop acidemia because of conversion of the citrate ion to bicarbonate, and in addition the animals did not develop renal hypertrophy. On the basis of these results it was argued that systemic acidemia induced the hypertrophic response. Studies by Haas and Simpson (34) have demonstrated that chronic metabolic acidosis induced by $\mathrm{NH}_{4} \mathrm{Cl}$ administration in the rat increases the rate of renal cortical protein synthesis. Van Thiel et al. (35) demonstrated that rats fed ethanol chronically developed renal hypertrophy, and suggested that renal growth may have resulted from the metabolic acidosis that the animals developed as a result of ethanol ingestion. Unlike in vivo acidemia, in vitro acidemia has never been demonstrated to induce cell hypertrophy (increased cell protein content in the absence of an increase in DNA synthesis) but instead results in either a decreased rate of cell growth in nonrenal cells (36) or an increased rate of DNA synthesis in renal cortical cells (37). A possible explanation of these discrepant results is that $\mathrm{NH}_{4} \mathrm{Cl}$ and ethanol administration in vivo caused acidemia, which subsequently resulted in an increase in renal ammonia production, and that the increased renal tissue ammonia concentration rather than the acidemia per se induced the hypertrophic response. Given the normal acid-base status of ammonium citrate-treated animals, renal ammoniagenesis would not have been expected to increase above normal.

The present study was designed to test the hypothesis that ammonia in the absence of extracellular acidemia can modulate renal cell growth. In addition, experiments were performed to determine whether normally functioning $\mathrm{Na}^{+} / \mathrm{H}^{+}$ antiport activity is required for hypertrophy to occur. The JTC 
cell line derived from monkey kidney proximal tubule, and cultured rabbit primary proximal tubule cells were used as model systems.

\section{Methods}

\section{Culture of JTC cells}

JTC cells were obtained from Dr. Paul A. Insel, Department of Pharmacology, University of California, San Diego. Cells (passage 12-25) were plated at a density of $\sim 5 \times 10^{5}$ cells $/ 76-\mathrm{cm}^{2}$ flask and maintained in a complete growth medium composed of DME, $10 \%$ newborn calf serum, $50 \mathrm{IU} / \mathrm{ml}$ penicillin, and $50 \mu \mathrm{g} / \mathrm{ml}$ streptomycin. Cultures were maintained in an incubator at $37^{\circ} \mathrm{C}$ in $95 \%$ air $-5 \% \mathrm{CO}_{2}$, $\mathrm{pH}$ 7.4. The cells were harvested with trypsin and then seeded onto either sterile glass coverslips (for studies requiring the monitoring of intracellular $\left.\mathrm{pH}\left[\mathrm{pH}_{\mathrm{i}}\right]\right)^{1}$ or $35-\mathrm{mm}$ petri dishes. In all studies, unless indicated, after the cells became confluent the monolayers were bathed for $96 \mathrm{~h}$ in serum-free DME (medium A) to achieve quiescence before altering the medium bathing the cells. To prevent cellular $\mathrm{H}^{+}$efflux from lowering the external $\mathrm{pH}$, after the cells achieved quiescence the medium bathing the cells was changed twice daily.

\section{Culture of rabbit tubule cells}

Primary cultures of rabbit proximal tubule epithelial cells were prepared as described previously $(38,39)$. Cells were grown to confluence in DME/Ham's F12 medium (1:1) supplemented with transferrin (5 $\mu \mathrm{g} / \mathrm{ml})$, insulin $(5 \mu \mathrm{g} / \mathrm{ml})$, and hydrocortisone $(50 \mathrm{nM})$. Insulin and hydrocortisone were removed from the medium for $48 \mathrm{~h}$ before the study to achieve quiescence. After the cells achieved quiescence the medium bathing the cells was changed twice daily to prevent the external $\mathrm{pH}$ from changing.

\section{Measurement of cell protein content}

JTC cells. Cell protein content was measured according to Sedmark and Grosberg (40) using BSA as a standard. Cell number was measured on the same petri dishes that were used for the cell protein assay. After the 96-h serum-free period (medium A) the cells were bathed in either serum-free DME (medium A), serum-free DME + $40 \mathrm{mM}$ mannitol (medium B), or serum-free DME $+20 \mathrm{mM} \mathrm{NH}_{4} \mathrm{Cl}$ (medium C) before study. Although the effective osmolality of the medium containing 40 $\mathrm{mM}$ mannitol exceeds the effective osmolality of the medium containing $20 \mathrm{mM} \mathrm{NH}_{4} \mathrm{Cl}, 40 \mathrm{mM}$ mannitol was used as an upper limit to rule out an effect of medium osmolality changes on cell protein content. To determine the time course of change in cell protein, the cell protein content was measured after $24,48,72$, and $96 \mathrm{~h}$ exposure to these solutions. In a separate study the dose dependence of $\mathrm{NH}_{4} \mathrm{Cl}$ addition (0-20 mM) on cell protein content was determined after $96 \mathrm{~h}$ exposure to $\mathrm{NH}_{4} \mathrm{Cl}$. In another series of experiments the effect of acute $\mathrm{NH}_{4} \mathrm{Cl}$ exposure $(10 \mathrm{~s})$ on cell protein content was measured $96 \mathrm{~h}$ later. Control JTC cell protein content was found to vary from $\sim 1.6$ to 2.2 $\times 10^{-4} \mu \mathrm{g} /$ cell; therefore, control cell protein measurements were always made with each experimental protocol.

Rabbit primary proximal tubule cells. After $48 \mathrm{~h}$ exposure to medium containing only transferrin, the cells were bathed in various concentrations of $\mathrm{NH}_{4} \mathrm{Cl}(0-20 \mathrm{mM})$ in medium containing only transferrin for $96 \mathrm{~h}$, at which time the cell protein content was measured.

\section{Measurement of protein synthetic rate}

After the 96-h serum-free period (medium A) the rate of protein synthesis was measured in cells bathed in either medium A, B, or C. Measurements were made after $24,48,72$, and $96 \mathrm{~h}$ exposure. On the

1. Abbreviations used in this paper: $\mathrm{BCECF}, 2^{\prime}, 7^{\prime}$-bis-(carboxyethyl)5,6 carboxyfluorescein; LFM, leucine-free media; NMec, 7-amino-4methylcoumarin; $\mathrm{pH}_{\mathrm{i}}$, intracellular $\mathrm{pH}$; $\mathrm{SNGFR}$, single nephron glomerular filtration rate. day of the study the DME medium bathing the cells was replaced by labeling medium identical to media $\mathrm{A}, \mathrm{B}$, and $\mathrm{C}$ except that leucinefree media (LFM) were used and supplemented with $\left[{ }^{3} \mathrm{H}\right]$ leucine $(1$ $\mu \mathrm{Ci} / \mathrm{ml}$, sp act $45 \mathrm{Ci} / \mathrm{mmol})$. The monolayers were exposed to these media for either $4 \mathrm{~h}$ or in separate experiments for $16 \mathrm{~h}$. After the labeling period the medium was replaced with LFM (otherwise identical to media A, B, and C) and supplemented with $2 \mathrm{mM}$ leucine (chase medium) for $3 \mathrm{~h}$. Then the monolayers were washed three times with the same media. The cells were harvested (trypsinized) and a cell count was performed on a $10-\mu l$ aliquot, followed by a TCA precipitation of the cell suspension, and radioactivity was then measured in the TCAinsoluble phase of the suspension. In the time-course studies the protein synthetic rate was expressed as counts/minute per cell after $16 \mathrm{~h}$ uptake. In a second series of experiments, to determine the dose-dependent effect of $\mathrm{NH}_{4} \mathrm{Cl}$ exposure on protein synthesis, JTC cells were exposed for $72 \mathrm{~h}$ to medium A plus varying concentrations of $\mathrm{NH}_{4} \mathrm{Cl}$ $(0-20 \mathrm{mM})$. In these studies the cells were exposed to $\left[{ }^{3} \mathrm{H}\right] \mathrm{leucine}$ for either $4 \mathrm{~h}$, or in separate experiments for $16 \mathrm{~h}$.

\section{Measurement of protein degradation rate}

After the 96-h serum-free period (medium A) the rate of protein degradation was measured in cells bathed in either medium A, B, or C. Measurements of the protein degradation rate were made at $24,48,72$, and $96 \mathrm{~h}$ exposure. To measure the rate of protein degradation the cells were exposed for $18 \mathrm{~h}$ to media identical to medium A, B, or C except that $\mathrm{LFM}$ was used and supplemented with $\left[{ }^{3} \mathrm{H}\right]$ leucine $(1 \mu \mathrm{Ci} / \mathrm{ml}, \mathrm{sp}$ act $45 \mathrm{Ci} / \mathrm{mmol})$. After the labeling period the media were replaced by LFM otherwise identical to media $A, B$, and $C$ and supplemented with $2 \mathrm{mM}$ leucine (chase media). After a 3-h incubation the monolayers were washed three times with the same media, then $1 \mathrm{ml}$ of fresh chase medium was added to each dish for $3 \mathrm{~h}$. The medium was removed and $1 \mathrm{mg}$ of bovine albumin per dish was added. The protein in the media was precipitated with $10 \%$ TCA and the suspension was centrifuged. The counts in the supernatant TCA-soluble (amino acid) and -insoluble (protein) fractions were measured. The cells were also exposed to $10 \%$ TCA, the suspension was centrifuged, and the counts were measured in the TCA-soluble (amino acid) and -insoluble (protein) fractions. Protein degradation rates were expressed as the ratio of the counts in the medium in the TCA-soluble (medium amino acid) fraction to the counts in the cells in the TCA-insoluble (cell protein) fraction that were released over $3 \mathrm{~h}$. Separate studies revealed that the counts in the medium from the TCA-insoluble (medium protein) fraction were constant and $<0.2 \%$ of the cell TCA-insoluble (cell protein) fraction. In separate experiments JTC cells were exposed to varying concentrations of $\mathrm{NH}_{4} \mathrm{Cl}(0-20 \mathrm{mM})$ for $72 \mathrm{~h}$ to determine the dose-dependent effect of $\mathrm{NH}_{4} \mathrm{Cl}$ exposure on protein degradation.

\section{Measurement of cell size, blastogenic index, and RNA content using flow cytometry}

JTC cells were bathed in medium A for $96 \mathrm{~h}$ and then exposed to medium $\mathrm{A}, \mathrm{B}$, or $\mathrm{C}$ for various periods of time. The cell monolayers were then trypsinized, washed twice with PBS, resuspended in $70 \%$ ethanol, and stored at $4^{\circ} \mathrm{C}$. For each sample, equal aliquots were washed twice with PBS. One aliquot was resuspended in $0.1 \mathrm{ml}$ PBS with $1.0 \mathrm{mg} / \mathrm{ml} \mathrm{RNAse} \mathrm{A.} \mathrm{The} \mathrm{other} \mathrm{was} \mathrm{resuspended} \mathrm{in} \mathrm{PBS.} \mathrm{Both}$ aliquots were incubated at $37^{\circ} \mathrm{C}$ for $30 \mathrm{~min}$. Each sample was then stained with propidium iodide $(1.0 \mathrm{ml}$ of a $50 \mu \mathrm{g} / \mathrm{ml}$ stock in hypotonic citrate; 41). Samples were allowed to equilibrate with the dye for $24 \mathrm{~h}$ at $4^{\circ} \mathrm{C}$ before analysis on an EPICS V cell sorter (Coulter Electronics Inc., Hialeah, FL). The following histograms were generated for each sample: (a) forward angle light scatter to estimate cell size (42), and $(b)$ linear fluorescences gated from the forward angle light scatter to perform a cell cycle analysis, assess the blastogenic index (43), and measure the RNA content per cell (44). A minimum of 10,000 cells were analyzed from each sample. Cell cycle analysis was performed by plotting the number of cells in the sample versus the quantity of DNA per cell (as measured by propidium iodide fluorescence). The blastogenic 
index, which is defined as the percentage of cells in the population that are in the $S+G_{2}+M$ phase of the cell cycle, was calculated using standard programs on the MDADS computer (Coulter Electronics Inc.). An estimate of the total cellular RNA content was determined by the difference in the $G_{1}$ peak of the samples treated with and without RNAse.

\section{Measurement of DNA synthetic rate}

$\left[{ }^{3} \mathrm{H}\right]$ Thymidine $(2 \mu \mathrm{Ci} / \mathrm{ml}$, sp act $35 \mathrm{Ci} / \mathrm{mmol}$; ICN Radiochemicals, Irvine, $\mathrm{CA}$ ) was added directly to the medium and cells were incubated for $2 \mathrm{~h}$ at $37^{\circ} \mathrm{C}$. $\left[{ }^{3} \mathrm{H}\right]$ Counts incorporated into TCA-precipitable material were measured in JTC cells exposed initially to medium A for $96 \mathrm{~h}$ and then to medium $\mathrm{A}+$ various concentrations of $\mathrm{NH}_{4} \mathrm{Cl}(0-20 \mathrm{mM})$ for the next $96 \mathrm{~h}$.

\section{Measurement of lysosomal enzyme cathepsins $L$ and $B$}

JTC cells were bathed in medium A for $96 \mathrm{~h}$ and then exposed to various concentrations of $\mathrm{NH}_{4} \mathrm{Cl}(0-20 \mathrm{mM})$. At $72 \mathrm{~h}$ exposure measurements of the cell content of the cathepsin L and B lysosomal enzymes were made (45). Standard curves were generated using 7amino-4-methylcoumarin (NMec; Enzyme Systems Products, Livermore, $\mathrm{CA}$ ) in various concentrations from 0.5 to $4 \mu \mathrm{M}$. NMec standards were made by diluting aliquots of a $100 \mu \mathrm{M}$ of NMec dissolved in DMSO with the assay buffer. The assay buffer contained $11.0 \mathrm{mM}$ $\mathrm{Na}_{2} \mathrm{HPO}_{4}, 55.2 \mathrm{mM} \mathrm{KH_{2 }} \mathrm{PO}_{4}$, and $4.0 \mathrm{mM}$ EDTA. 10-mM stock solutions of the two lysosomal enzyme substrates used in the lysosomal assay, Z-Phe-Arg-NMec (for cathepsin L) and Z-Arg-NMec (for cathepsin B), were made by dissolving each compound in DMSO to a final concentration of $10 \mathrm{mM}$. On the day of the study the stock solutions of the lysosomal enzyme substrates were diluted to $1 \mathrm{mM}$ with $0.1 \%$ Brij 35 . The stop solution used in the assay contained $100 \mathrm{mM}$ sodium monochloroacetate in a sodium acetate buffer consisting of $30 \mathrm{mM}$ sodium acetate and $70 \mathrm{mM}$ acetic acid, $\mathrm{pH}$ 4.3. To assay the cell lysosomal enzyme content the cell monolayers were trypsinized and the suspension centrifuged. The pellet was resuspended in PBS. A cell count was performed on a $10-\mu l$ aliquot. The suspension was recentrifuged and the supernatant was removed. The pellet was resuspended in the assay buffer with $0.2 \%$ Triton $\mathrm{X}$ and the cell suspension was frozen for $15 \mathrm{~min}$ and then thawed in a $37^{\circ} \mathrm{C}$ water bath. Equal volumes of the cell homogenate and substrate where mixed and incubated at $37^{\circ} \mathrm{C}$ in a water bath (for $20 \mathrm{~min}$ ). Then the mixture was taken out and placed on ice and the reaction was stopped by adding ice-cold stop solution. The fluorescence of samples was measured in an fluorometer (LS-5; Perkin-Elmer Corp., Norwalk, CT) at an excitation wavelength of $365 \mathrm{~nm}$ and an emission wavelength of $450 \mathrm{~nm}$ using 3-nm slits. The enzyme activity was expressed as picomoles of NMec released per minute per cell.

\section{Measurement of $\mathrm{pH}_{i}$}

JTC cells were grown to confluency on glass coverslips. $\mathrm{pH}_{\mathrm{i}}$ was measured with 2',7'-bis-(carboxyethyl)-5,6 carboxyfluorescein (BCECF) as previously described using an LS-5 fluorometer (46). Calibration of intracellular BCECF fluorescent excitation ratios was performed after each experiment using high- $\mathrm{K}^{+}$nigericin solutions set to various external $\mathrm{pH}$ values (46).

\section{Measurement of $\mathrm{Na}^{+} / \mathrm{H}^{+}$antiport activity}

The cells were acid-loaded by exposure to and subsequent removal of $\mathrm{NH}_{4} \mathrm{Cl}(20 \mathrm{mM})$ in the absence of sodium in Hepes-buffered solutions (47). Cell buffer capacity $(\beta)$ was measured after removal of $\mathrm{NH}_{4} \mathrm{Cl}$ in the absence of sodium (47). The amiloride-inhibitable, $\mathrm{Na}^{+}$-dependent rate of $\mathrm{H}^{+}$efflux was calculated according to the formula $\mathrm{H}^{+}$efflux $=\beta$ $\times d \mathrm{pH}_{\mathrm{i}} / d t$ where $d \mathrm{pH}_{\mathrm{i}} / d t$ is the rate of amiloride-inhibitable, $\mathrm{Na}^{+}$-dependent $\mathrm{pH}_{\mathrm{i}}$ recovery measured in the initial $45 \mathrm{~s}$.

\section{Solutions}

Steady state of $\mathrm{pH}_{\mathrm{i}}$ was measured in cells bathed in a solution containing $115 \mathrm{mM} \mathrm{NaCl}, 2.5 \mathrm{mM} \mathrm{K}_{2} \mathrm{HPO}_{4}, 25 \mathrm{mM} \mathrm{NaHCO}_{3}, 1 \mathrm{mM} \mathrm{CaCl}_{2}$,
$1 \mathrm{mM} \mathrm{MgCl}$, and $5 \mathrm{mM}$ glucose. The solution was gassed with $95 \%$ $\mathrm{O}_{2} / 5 \% \mathrm{CO}_{2}$, $\mathrm{pH} 7.4$ (solution $\mathrm{A}$ ). In separate experiments $\mathrm{pH}_{\mathrm{i}}$ was measured in cells bathed in a solution otherwise identical to solution $\mathrm{A}$ containing 2 or $20 \mathrm{mM} \mathrm{NH}_{4} \mathrm{Cl}$. To measure the rate of $\mathrm{Na}^{+} / \mathrm{H}^{+}$antiport activity the cells were loaded with $\mathrm{BCECF}$ in a $\mathrm{Na}^{+}$-free solution containing $20 \mathrm{mM} \mathrm{NH}_{4} \mathrm{Cl}$ for $5 \mathrm{~min}: 120 \mathrm{mM} \mathrm{TMACl}, 2.5 \mathrm{mM}$

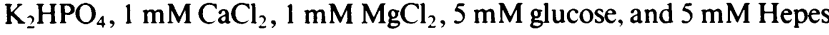
and gassed with $100 \% \mathrm{O}_{2}, \mathrm{pH} 7.4$ (solution $\mathrm{B}$ ). Then $\mathrm{NH}_{4} \mathrm{Cl}$ was removed by bathing the cells in a solution containing $140 \mathrm{mM}$ TMACl, $2.5 \mathrm{mM} \mathrm{K}_{2} \mathrm{HPO}_{4}, 1 \mathrm{mM} \mathrm{CaCl}_{2}, 1 \mathrm{mM} \mathrm{MgCl}, 5 \mathrm{mM}$ glucose, and $5 \mathrm{mM}$ Hepes and gassed with $100 \% \mathrm{O}_{2}, \mathrm{pH} 7.4$ (solution $\mathrm{C}$ ). The $\mathrm{Na}^{+}$-dependent recovery rate was measured after the readdition of a solution identical to solution $\mathrm{C}$ except that TMACl $(140 \mathrm{mM})$ was replaced with $\mathrm{NaCl}(140 \mathrm{mM})$ (solution $\mathrm{D})$.

\section{Materials}

BCECF-AM was from Molecular Probes Inc., Junction City, OR; $\left[{ }^{3} \mathrm{H}\right]$ leucine and $\left[{ }^{3} \mathrm{H}\right]$ thymidine were from ICN Radiochemicals; propidium iodide and RNAse were from Calbiochem-Behring Corp., San Diego, CA; DME and FCS were from Gibco Laboratories, Grand Island, NY; leucine, TCA, DNAse 1, amiloride $\mathrm{HCl}$, DMSO, and Triton X-100 were from Sigma Chemical Co., St. Louis, MO; mannitol, $\mathrm{NH}_{4} \mathrm{Cl}$, and EDTA were from Fisher Scientific Co., Pittsburgh, PA; NMec, Z-Phe-Arg-NMec, and Z-Arg-NMec were from Enzyme Systems Products; and sodium monochloroacetate and Brij 35 were from Eastman Kodak Co., Rochester, NY.

\section{Statistics}

The results are expressed as mean \pm SEM. The unpaired $t$ test was used as required to compare two group means. When a protocol involved more than three group means Dunnett's $t$ test (48) was used to compare each experimental group with the same control group. $n$ refers to the number of cell monolayers used to derive a mean value for a given protocol. Monolayers were assigned randomly to the experimental groups.

\section{Results}

Effect of $\mathrm{NH}_{4} \mathrm{Cl}$ on cell protein content. The protein content of the cells bathed in medium A, B, or C for 24-72 $\mathrm{h}$ was not significantly different. However, at $96 \mathrm{~h}$ the protein content of the cells exposed to $20 \mathrm{mM} \mathrm{NH} \mathrm{m}_{4} \mathrm{Cl}$ (medium C) was significantly increased $\left(5.24 \pm 0.47 \times 10^{-4} \mu \mathrm{g} /\right.$ cell, $n=4, P<0.01$ vs. DME; $P<0.02$ vs. DME $+40 \mathrm{mM}$ mannitol; Fig. 1), whereas the cell protein content had remained unchanged in cells bathed in media A and B. Since renal cortical cells are not exposed to $20 \mathrm{mM}$ ammonium in vivo, JTC cells were exposed to either 0 or $2 \mathrm{mM} \mathrm{NH}_{4} \mathrm{Cl}$ to determine whether hypertrophy

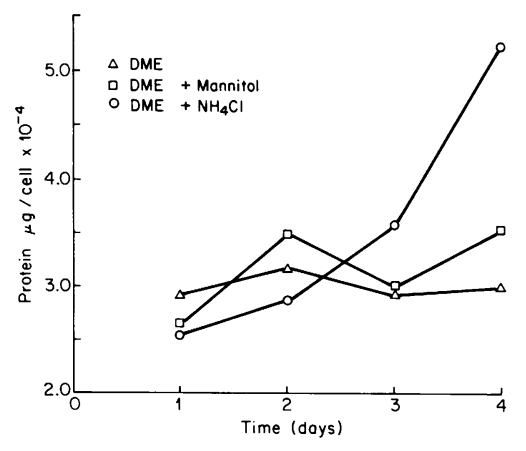

Figure 1. Effect of $\mathrm{NH}_{4} \mathrm{Cl}$ on cell protein content in JTC cells (time course). JTC cells were exposed to serumfree DME (medium A) for $96 \mathrm{~h}$ and then to either serum-free DME (medium A), serum-free $\mathrm{DME}+40 \mathrm{mM}$ mannitol (medium B), or serum-free DME + 20 $\mathrm{mM} \mathrm{NH}_{4} \mathrm{Cl}$ (medium C). Cell protein content was measured after $24,46,72$, and $96 \mathrm{~h}$. Each point represents the mean of four determinations. 
could be induced by this more physiologically relevant concentration of $\mathrm{NH}_{4} \mathrm{Cl}$. As shown in Fig. 2, $96 \mathrm{~h}$ exposure to $\mathrm{DME}+2 \mathrm{mM} \mathrm{NH}_{4} \mathrm{Cl}$ caused the cell protein content to increase from $1.63 \pm 0.09 \times 10^{-4} \mu \mathrm{g} /$ cell $(n=4)$ to $2.28 \pm 0.18$ $\times 10^{-4} \mu \mathrm{g} /$ cell $(n=5), P<0.001$. To determine the dose dependence of this effect cells were exposed to various concentrations of $\mathrm{NH}_{4} \mathrm{Cl}(0-20 \mathrm{mM})$ in the presence (Fig. $3 a$ ) and absence (Fig. $3 \mathrm{~b}$ ) of serum, and the cell protein content was measured after $96 \mathrm{~h}$ exposure. As depicted in Fig. $3 a, \mathrm{NH}_{4} \mathrm{Cl}$ exposure caused a dose-dependent increase in cell protein content without plateauing at $20 \mathrm{mM}$. As shown in Fig. $3 b$, the results were qualitatively similar in the serum-free studies. To rule out the possibility that $\mathrm{NH}_{4} \mathrm{Cl}$ was only capable of inducing hypertrophy in a continuous renal cell line such as JTC cells, further experiments on a primary culture of rabbit proximal tubule cells were performed. As shown in Fig. 4, after $96 \mathrm{~h}$ exposure $\mathrm{NH}_{4} \mathrm{Cl}(0-20 \mathrm{mM})$ induced a dose-dependent increase in cell protein in a primary culture of rabbit proximal tubule cells. Protein content increased in a dose-dependent fashion from $5.80 \pm 0.53 \times 10^{-4} \mu \mathrm{g} /$ cell $(n=4)$ to $12.9 \pm 0.73$ $\times 10^{-4} \mu \mathrm{g} /$ cell $(n=4), P<0.01$. As in JTC cells, the effect did not plateau at $20 \mathrm{mM} \mathrm{NH}{ }_{4} \mathrm{Cl}$.

In a previous study of proximal tubule cells an inverse relationship was documented between cell number and cell protein content, when cell number decreased to $<\sim 50 \%$ of the control value (49). As summarized in Table I, only in 15 and $20 \mathrm{mM} \mathrm{NH}_{4} \mathrm{Cl}$ was cell number significantly decreased in JTC cells, suggesting that at these higher doses a decrease in cell density could have contributed in part to the observed increase in cell protein content.

Effect of acute $\mathrm{NH}_{4} \mathrm{Cl}$ exposure on cell protein content. It is well documented that $\mathrm{NH}_{4} \mathrm{Cl}$ exposure results in an initial rapid rise in $\mathrm{pH}_{\mathrm{i}}$, which peaks in $<5 \mathrm{~s}$ and is due to the rapid cellular influx of $\mathrm{NH}_{3}(47,50)$. The rise in $\mathrm{pH}_{\mathrm{i}}$ is followed immediately by a return of $\mathrm{pH}_{\mathrm{i}}$ to baseline due to the influx of $\mathrm{NH}_{4}^{+}$and stimulation of $\mathrm{Cl}^{-}$/base exchange (46). It has previously been shown that a rise in $\mathrm{pH}_{\mathrm{i}}$ resulting from a stimulation of $\mathrm{Na}^{+} / \mathrm{H}^{+}$antiport activity is an important signaling event that results in growth of sea urchin eggs (51).

To determine whether the acute rise in $\mathrm{pH}_{\mathrm{i}}$ induced by exposure to $20 \mathrm{mM} \mathrm{NH}_{4} \mathrm{Cl}$ was sufficient to cause cell hypertrophy, JTC cells were acutely exposed to serum-free DME $+20 \mathrm{mM} \mathrm{NH}_{4} \mathrm{Cl}$ for $10 \mathrm{~s}$ and thereafter serum-free DME only. In this protocol $\mathrm{pH}_{\mathrm{i}}$ increased $\sim 0.5 \mathrm{pH}$ units after $\mathrm{NH}_{4} \mathrm{Cl}$ exposure and returned to baseline after the removal of $\mathrm{NH}_{4} \mathrm{Cl}$ (data not shown). $\mathrm{pH}_{\mathrm{i}}$ did not decrease below the baseline value because the short exposure did not permit sufficient $\mathrm{NH}_{4}^{+}$to enter the cells. $96 \mathrm{~h}$ after the acute exposure to $20 \mathrm{mM}$

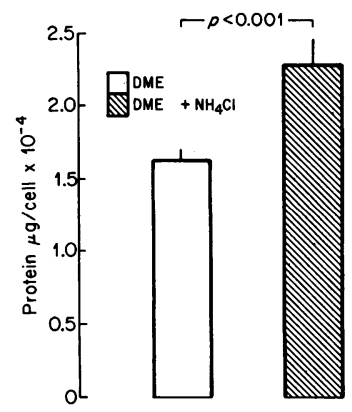

Figure 2. Effect of $2 \mathrm{mM} \mathrm{NH}_{4} \mathrm{Cl}$ on JTC cell protein content $(96 \mathrm{~h}$ exposure). JTC cells were exposed to serum-free DME (medium A) for 96 $h$ and then to either serum-free DME (medium A) or serum-free DME + 2 $\mathrm{mM} \mathrm{NH}_{4} \mathrm{Cl}$ for the following $96 \mathrm{~h} .2$ $\mathrm{mM} \mathrm{NH}_{4} \mathrm{Cl}$ induced a significant increase in cell protein content.
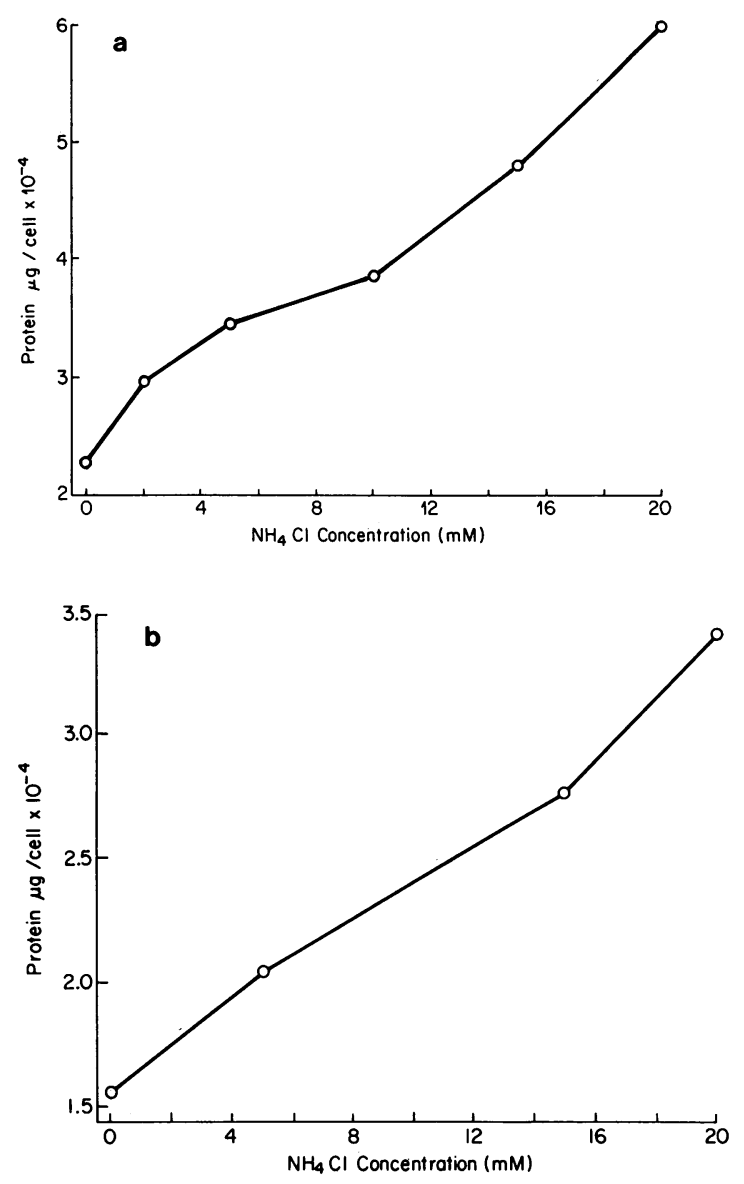

Figure 3. Effect of $\mathrm{NH}_{4} \mathrm{Cl}$ on cell protein content in JTC cells (dose response). JTC cells were exposed to DME + various concentrations $(0-20 \mathrm{mM})$ of $\mathrm{NH}_{4} \mathrm{Cl}$ for $96 \mathrm{~h}$ in the presence $(a)$ and absence $(b)$ of serum. Each point represents the mean of at least three determinations.

$\mathrm{NH}_{4} \mathrm{Cl}$, protein content was $2.27 \pm 0.10 \times 10^{-4} \mu \mathrm{g} /$ cell $(n=5)$, which was not significantly different from control cells, $2.22 \pm 0.11 \times 10^{-4} \mu \mathrm{g} / \mathrm{cell}(n=5)$. These results suggest that the acute rise in $\mathrm{pH}_{\mathrm{i}}$ resulting from $\mathrm{NH}_{4} \mathrm{Cl}$ exposure is not sufficient to induce hypertrophy in JTC cells.

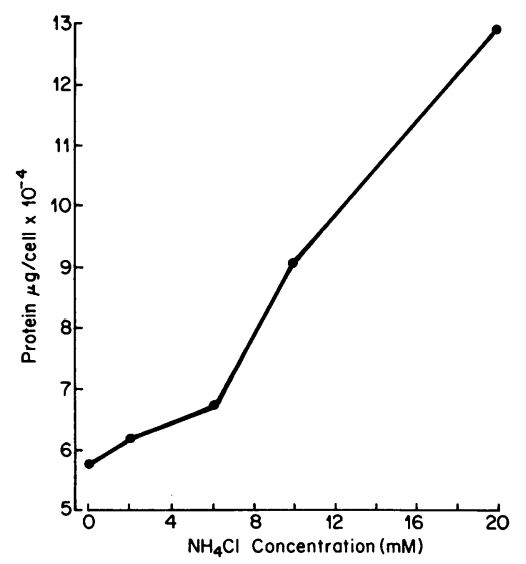

Figure 4. Effect of $\mathrm{NH}_{4} \mathrm{Cl}$ on cell protein content of rabbit proximal cells in primary culture ( $96 \mathrm{~h}$ exposure). The cells were exposed to serum-free DME/ Ham's F12 medium (1:1) in the absence of insulin and hydrocortisone for $48 \mathrm{~h}$ and thereafter to the same medium + various concentrations of $\mathrm{NH}_{4} \mathrm{Cl}(0-20$ $\mathrm{mM}$ ) for the next $96 \mathrm{~h}$. Each point represents the mean of four determinations. 
Table I. Effect of $\mathrm{NH}_{4} \mathrm{Cl}$ on Cell Number (96 h Exposure)

\begin{tabular}{rc}
\hline $\mathrm{NH}_{4} \mathrm{Cl}$ & Cell number \\
\hline$m M$ & $\times 10^{4} / 35-\mathrm{mm}$ dish $^{*}$ \\
0 & $65.0 \pm 4.4$ \\
2 & $62.2 \pm 4.7$ \\
5 & $54.3 \pm 4.8$ \\
10 & $59.9 \pm 4.4$ \\
15 & $50.7 \pm 2.3^{\ddagger}$ \\
20 & $46.4 \pm 4.8^{\ddagger}$ \\
\hline
\end{tabular}

* The results represent the mean of three to five studies. For each study, three to six culture dishes were used to calculate the value for each experimental group.

$\ddagger P<0.05$ vs. $0 \mathrm{mM} \mathrm{NH}_{4} \mathrm{Cl}$.

Measurement of DNA synthetic rate, blastogenic index, and cell cycle analysis. Changes in cell protein content induced by $\mathrm{NH}_{4} \mathrm{Cl}$ exposure may have resulted from a stimulation of cell proliferation (hyperplastic response). Therefore, thymidine incorporation was measured as an index of DNA synthesis to determine whether $\mathrm{NH}_{4} \mathrm{Cl}$ induced a hyperplastic vs. a hypertrophic response. As Fig. 5 depicts, thymidine incorporation/cell was unaffected by exposure of the cells for $96 \mathrm{~h}$ to various concentrations of $\mathrm{NH}_{4} \mathrm{Cl}(0-20 \mathrm{mM})$, which indicates that $\mathrm{NH}_{4} \mathrm{Cl}$ induces an in vitro model of cell hypertrophy rather than hyperplasia. To confirm the interpretation that $\mathrm{NH}_{4} \mathrm{Cl}$ exposure does not induce hyperplasia in JTC cells, a cell cycle analysis was performed using the flow cytometer (Fig. 6) and the blastogenic index was calculated after 24,48 , and $72 \mathrm{~h}$ exposure to either medium A, B, or C (Table II). As depicted in Table II, after $24 \mathrm{~h}$ in serum-free media the blastogenic index was $\sim 15 \%$ in all experimental groups and subsequently decreased to $<10 \%$ after $72 \mathrm{~h}$ in serum-free media. The results indicate that the percentage of cells in the population that were in $\mathrm{G}_{0}$ was not affected by $\mathrm{NH}_{4} \mathrm{Cl}$ exposure. These results complement the $\left[{ }^{3} \mathrm{H}\right]$ thymidine incorporation data and indicate that $\mathrm{NH}_{4} \mathrm{Cl}$ exposure does not induce hyperplasia in JTC cells.

Effect of $\mathrm{NH}_{4} \mathrm{Cl}$ on cell size. Further experiments were performed to determine whether in addition to increasing the protein content of JTC cells, $\mathrm{NH}_{4} \mathrm{Cl}$ increases the cell size.

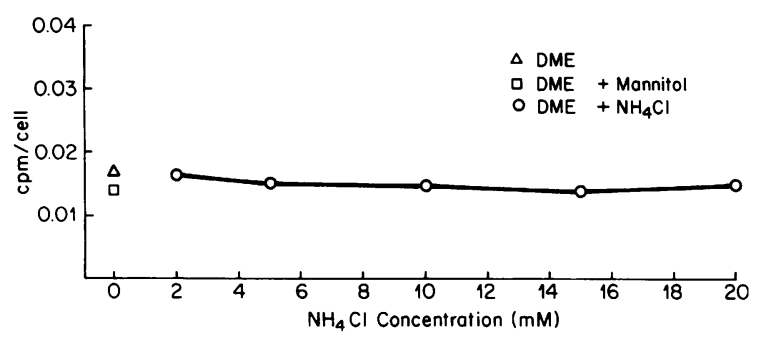

Figure 5. Effect of $\mathrm{NH}_{4} \mathrm{Cl}$ on DNA synthesis in JTC cells as assessed by $2-\mathrm{h}\left[{ }^{3} \mathrm{H}\right]$ thymidine incorporation ( $96 \mathrm{~h}$ exposure). JTC cells were bathed in serum-free DME (medium A) for $96 \mathrm{~h}$ and the rate of DNA synthesis was measured after the cells were exposed for the next $96 \mathrm{~h}$ to serum-free DME + various concentrations of $\mathrm{NH}_{4} \mathrm{Cl}$ $(0-20 \mathrm{mM})$. Each point represents the mean of at least four determinations. The results indicate that $\mathrm{NH}_{4} \mathrm{Cl}$ does not induce cell hyperplasia.

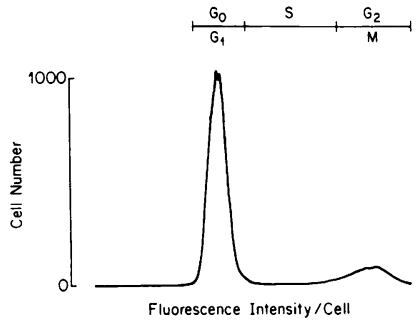

Figure 6. Cell cycle analysis of JTC cells bathed in serum-free DME medium (medium $A$ ) for $96 \mathrm{~h}$. Note that most of the cells are in $\mathrm{G}_{0}$.

Using the forward angle light scattering technique, the cell size was assessed qualitatively in a flow cytometer in cells exposed to medium A, B, or C. As depicted in Fig. 7, the size distribution of cells bathed in $20 \mathrm{mM} \mathrm{NH}_{4} \mathrm{Cl}$ (medium C) was increased.

Effect of $\mathrm{NH}_{4} \mathrm{Cl}$ on protein synthetic rate. Increase in cell protein content after exposure of JTC cells to $\mathrm{NH}_{4} \mathrm{Cl}$ could have been due to an increase in the protein synthetic rate and/or a decrease in the protein degradation rate. To clarify this issue the protein synthetic rate was assessed by measuring $\left[{ }^{3} \mathrm{H}\right]$ leucine incorporation in $16 \mathrm{~h}$. Table III shows that after 24 $h$ exposure to $\mathrm{NH}_{4} \mathrm{Cl}$ the rate of protein synthesis had increased significantly. The increase in protein synthesis remained elevated up to $96 \mathrm{~h}$ exposure. Cells were then exposed to various concentrations of $\mathrm{NH}_{4} \mathrm{Cl}(0-20 \mathrm{mM})$ for $72 \mathrm{~h}$. As summarized in Table IV, $\mathrm{NH}_{4} \mathrm{Cl}$ caused a dose-dependent increase in protein synthesis $\left(4\right.$ and $16 \mathrm{~h}\left[{ }^{3} \mathrm{H}\right]$ leucine incorporation). These results indicate that the increase in JTC cell protein content induced by $\mathrm{NH}_{4} \mathrm{Cl}$ results in part from a stimulation of the protein synthetic rate.

Effect of $\mathrm{NH}_{4} \mathrm{Cl}$ on cytoplasmic $\mathrm{RNA}$ content. To determine whether an increase in the protein synthetic rate was associated with an increase in cytoplasmic RNA, total cytoplasmic RNA content was measured using a flow cytometric assay after $72 \mathrm{~h}$ exposure to medium A, B, or C. As depicted in Fig. 8, $\mathrm{NH}_{4} \mathrm{Cl}$ exposure significantly increased the RNA content of the cells. Associated with an increase in cell RNA content was an increase in ribosome number as depicted in Fig. 9, $a$ and $b$ ).

Effect of $\mathrm{NH}_{4} \mathrm{Cl}$ on the protein degradation rate. $\mathrm{NH}_{4} \mathrm{Cl}$ has been previously been shown to decrease the rate of protein degradation in cultured hepatocytes (25), rat fibroblasts (26), and mouse macrophages (27), presumably due to its effect on lysosomal pH (26; see Discussion). Therefore, further studies were performed to determine whether the protein degradation rate was decreased in $\mathrm{JTC}$ cells exposed to $\mathrm{NH}_{4} \mathrm{Cl}$. The results are expressed as percentage of total cell protein that was de-

Table II. Blastogenic Index

\begin{tabular}{lccc}
\hline & \multicolumn{3}{c}{ Time (h) after serum removal } \\
\cline { 2 - 4 } & $24 \mathrm{~h}$ & $48 \mathrm{~h}$ & $72 \mathrm{~h}$ \\
\hline $\mathrm{DME}$ & $15.0 \%$ & $5.8 \%$ & $8.8 \%$ \\
$\mathrm{DME}+$ mannitol $(40 \mathrm{mM})$ & $17.4 \%$ & $7.7 \%$ & $7.7 \%$ \\
$\mathrm{DME}+\mathrm{NH}_{4} \mathrm{Cl}(20 \mathrm{mM})$ & $18.7 \%$ & $4.7 \%$ & $6.9 \%$ \\
\hline
\end{tabular}

Blastogenic index is defined as the percentage of cells in the population that are in the $S+G_{2}+M$ phase of the cell cycle. Each result was calculated by measuring a total of 10,000 cells. 

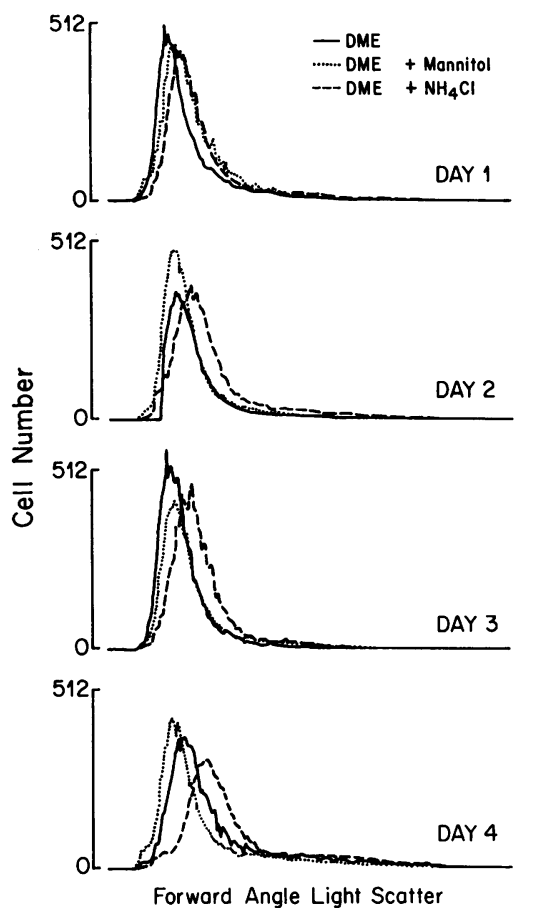

Figure 7. Cell size analysis (time course). Population cell size was analyzed qualitatively using the flow cytometer forward angle light scattering technique (see Methods). Cells were exposed to serumfree DME (medium A) for $96 \mathrm{~h}$ and then to either serum-free DME (medium A), serum-free $\mathrm{DME}+40 \mathrm{mM}$ mannitol (medium B), or serum-free DME + 20 $\mathrm{mM} \mathrm{NH}_{4} \mathrm{Cl}$ (medium C) for $24,48,72$, or 96 $h$. The mean population cell size increased in the $\mathrm{NH}_{4} \mathrm{Cl}$-treated group at 48,72 , and 96 $\mathrm{h}$ when compared with cells exposed to medium $\mathrm{A}$ or $\mathrm{B}(P<0.01)$.

graded in $3 \mathrm{~h}$ because of the well-documented linear relationship between cell protein content and the protein degradation rate. As Table $\mathrm{V}$ shows, by $24 \mathrm{~h}$ exposure the percent of cell protein degraded in the $\mathrm{NH}_{4} \mathrm{Cl}$-treated cells was significantly decreased. In a separate series of experiments the dose dependence of this effect was determined after $72 \mathrm{~h}$ exposure to 0-20 $\mathrm{mM} \mathrm{NH}_{4} \mathrm{Cl}$. As summarized in Table VI, by $24 \mathrm{~h}$ exposure $\mathrm{NH}_{4} \mathrm{Cl}$ decreased the protein degradation rate in JTC cells. The inability to detect a significant increase in cell protein content until $96 \mathrm{~h}$ exposure (Fig. 1) despite a significant change in cell protein turnover before this time is probably due to the greater sensitivity of the protein turnover studies.

Effect of $\mathrm{NH}_{4} \mathrm{Cl}$ on lysosomal enzymes content (cathepsins $B$ and $L$ ). It has previously been suggested that $\mathrm{NH}_{4} \mathrm{Cl}$ decreases the protein degradation rate in hepatocytes by inhibiting lysosomal enzyme function (25). This presumably occurs as a result of a rise in lysosomal $\mathrm{pH}$ induced by the passive entry of $\mathrm{NH}_{3}$. An elevation in lysosomal $\mathrm{pH}$ inhibits the lysosomal reuptake of mannose-6-phosphate-coupled enzymes and increases the cellular efflux of these enzymes (52). JTC cells were exposed to $\mathrm{NH}_{4} \mathrm{Cl}(0-20 \mathrm{mM})$ for $72 \mathrm{~h}$ after which measurements of lysosomal enzyme activity were made. As

shown in Table VII, the cathepsin B activity decreased from $0.51 \pm 0.001(n=4)$ to $0.28 \pm 0.001 \mathrm{pmol} / \mathrm{min}$ per cell $(n=5), P$ $<0.01$, in a dose-dependent fashion. Similarly, cathepsin L activity decreased from $0.43 \pm 0.001(n=4)$ to $0.17 \pm 0.001$ $\mathrm{pmol} / \mathrm{min}$ per cell $(n=5), P<0.01$, as the $\mathrm{NH}_{4} \mathrm{Cl}$ concentration increased from 0 to $20 \mathrm{mM}$. In addition, as depicted in Fig. 9, $a$ and $b \mathrm{NH}_{4} \mathrm{Cl}$ exposure resulted in lysosomal swelling and the accumulation of electron-dense material in the lysosomes.

Effect of $\mathrm{NH}_{4} \mathrm{Cl}$ on $\mathrm{pH}_{i}$. In the present study cell hypertrophy was induced by $\mathrm{NH}_{4} \mathrm{Cl}$ exposure in the absence of extracellular acidemia. To determine whether $\mathrm{pH}_{\mathrm{i}}$ was altered in cells chronically exposed to $\mathrm{NH}_{4} \mathrm{Cl}, \mathrm{pH}_{\mathrm{i}}$ was measured with BCECF. Since a hypertrophic response was detected in cells exposed to the more physiologic concentration of $2 \mathrm{mM}$ $\mathrm{NH}_{4} \mathrm{Cl}, \mathrm{pH}_{\mathrm{i}}$ was measured initially at this concentration. JTC cells were bathed for $96 \mathrm{~h}$ in medium A to achieve quiescence and then bathed in either medium A or serum-free DME + 2 $\mathrm{mM} \mathrm{NH}_{4} \mathrm{Cl}$ for up to $96 \mathrm{~h}$. As depicted in Fig. $10 a, \mathrm{pH}_{\mathrm{i}}$ was unaffected by $2 \mathrm{mM} \mathrm{NH}_{4} \mathrm{Cl}$ exposure, indicating that cell hypertrophy can occur in the absence of intracellular or extracellular acidemia. In cells exposed to $20 \mathrm{mM} \mathrm{NH}_{4} \mathrm{Cl}$ for $96 \mathrm{~h}$ (Fig. $10 \mathrm{~b}) \mathrm{pH}_{\mathrm{i}}$ was slightly decreased at 24 and $48 \mathrm{~h}$ exposure but was not significantly different from control at the remaining time points.

Effect of $\mathrm{NH}_{4} \mathrm{Cl}$ on the rate of $\mathrm{Na}^{+} / \mathrm{H}^{+}$antiport activity. JTC cells were bathed in medium A for $96 \mathrm{~h}$. Then the rate of $\mathrm{Na}^{+} / \mathrm{H}^{+}$antiport activity was measured in cells exposed to either medium A or serum-free DME $+2 \mathrm{mM} \mathrm{NH}_{4} \mathrm{Cl}$ for 24 and $72 \mathrm{~h}$. As depicted in Fig. 11, the rate of $\mathrm{Na}^{+} / \mathrm{H}^{+}$activity was not significantly affected by exposure to $2 \mathrm{mM} \mathrm{NH}_{4} \mathrm{Cl}$. After exposure of JTC cells to $2 \mathrm{mM} \mathrm{NH}_{4} \mathrm{Cl}$, the lack of detectable increase in $\mathrm{Na}^{+} / \mathrm{H}^{+}$antiport activity may have been due to the insensitivity of the methodology. Therefore, JTC cells were exposed to $20 \mathrm{mM} \mathrm{NH}_{4} \mathrm{Cl}$ (medium C) and the rate of $\mathrm{Na}^{+} / \mathrm{H}^{+}$antiport activity was measured after 24 and $72 \mathrm{~h}$ exposure. The results shown in Fig. 11 demonstrate that unlike 2 $\mathrm{mM} \mathrm{NH}{ }_{4} \mathrm{Cl}$, after $72 \mathrm{~h}$ exposure to $20 \mathrm{mM} \mathrm{NH}_{4} \mathrm{Cl}$ the rate of $\mathrm{H}^{+}$efflux via the $\mathrm{Na}^{+} / \mathrm{H}^{+}$antiporter increased significantly from 7.93 to $0.49 \mathrm{mM} / \mathrm{min}(n=5)$ to $12.4 \pm 2.20 \mathrm{mM} / \mathrm{min}(n$ $=3), P<0.05$.

Effect of $\mathrm{NH}_{4} \mathrm{Cl}$ on cell protein in amiloride-treated cells. To determine whether stimulation of the plasma membrane $\mathrm{Na}^{+} / \mathrm{H}^{+}$antiporter was required for cell hypertrophy to occur, JTC cells were exposed to either serum-free DME (medium A), serum-free DME + $20 \mathrm{mM} \mathrm{NH}_{4} \mathrm{Cl}$ (medium C), serumfree DME + $1 \mathrm{mM}$ amiloride, or DME $+20 \mathrm{mM} \mathrm{NH}_{4} \mathrm{Cl}$ plus 1 $\mathrm{mM}$ amiloride for $96 \mathrm{~h}$. The basal cell protein content in cells

Table III. Protein Synthetic Rate (Counts per Minute/Cell; 16-h Uptake)

\begin{tabular}{|c|c|c|c|c|c|}
\hline & \multirow[b]{2}{*}{$n$} & \multicolumn{4}{|c|}{ Exposure time } \\
\hline & & $24 \mathrm{~h}$ & $48 \mathrm{~h}$ & $72 \mathrm{~h}$ & $96 \mathrm{~h}$ \\
\hline DME & 4 & $0.25 \pm 0.02$ & $0.21 \pm 0.02$ & $0.29 \pm 0.02$ & $0.26 \pm 0.02^{*}$ \\
\hline $\mathrm{DME}+$ mannitol $(40 \mathrm{mM})$ & 4 & $0.27 \pm 0.01^{\ddagger}$ & $0.20 \pm 0.01$ & $0.28 \pm 0.02$ & - \\
\hline $\mathrm{DME}+\mathrm{NH}_{4} \mathrm{Cl}(20 \mathrm{mM})$ & 4 & $0.35 \pm 0.01^{8 \|}$ & $0.33 \pm 0.02^{114}$ & $0.41 \pm 0.02^{\ddagger \| * *}$ & $0.37 \pm 0.02 * \S$ \\
\hline
\end{tabular}

${ }^{*} n=8 ;{ }^{\ddagger} n=3 ;{ }^{\S} P<0.01 \mathrm{DME}+\mathrm{NH}_{4} \mathrm{Cl}(20 \mathrm{mM})$ vs. $\mathrm{DME} ; " ~ P<0.01 \mathrm{DME}+\mathrm{NH}_{4} \mathrm{Cl}(20 \mathrm{mM})$ vs. DME + mannitol $(40 \mathrm{mM}) ; " P<0.05$ $\mathrm{DME}+\mathrm{NH}_{4} \mathrm{Cl}(20 \mathrm{mM})$ vs. DME; ${ }^{* *} P<0.02 \mathrm{DME}+\mathrm{NH}_{4} \mathrm{Cl}(20 \mathrm{mM})$ vs. DME. 
Table IV. Increase in Protein Synthetic Rate after $72 \mathrm{~h}$ Exposure to $\mathrm{NH}_{4} \mathrm{Cl}$

\begin{tabular}{ccc}
\hline $\mathrm{NH}_{4} \mathrm{Cl}$ & \multicolumn{2}{c}{ Uptake of $\left[{ }^{3} \mathrm{H}\right]$ leucine } \\
\hline$m M$ & cpm/cell; 4 - $h$ uptake & cpm/cell; $16-h$ uptake \\
& $0.071 \pm 0.001(n=4)$ & $0.21 \pm 0.01(n=4)$ \\
2 & $0.068 \pm 0.002(n=5)$ & $0.23 \pm 0.01(n=5)$ \\
5 & $0.079 \pm 0.002(n=5)$ & $0.30 \pm 0.01(n=2)$ \\
10 & $0.088 \pm 0.002(n=5)$ & $0.31 \pm 0.02(n=4)$ \\
20 & $0.094 \pm 0.002(n=5)$ & $0.36 \pm 0.03(n=4)$
\end{tabular}

bathed in serum-free DME was $1.56 \pm 0.11 \times 10^{-4} \mu \mathrm{g} /$ cell $(n$ $=6$ ). In the cells exposed to $20 \mathrm{mM} \mathrm{NH}_{4} \mathrm{Cl}$ cell protein content increased to $3.42 \pm 0.18 \times 10^{-4} \mu \mathrm{g} /$ cell $(n=6)$ (Fig. 12; $119 \pm 16 \%$ increase, $P<0.001)$. Protein content of cells exposed to serum-free DME $+1 \mathrm{mM}$ amiloride was $1.99 \pm 0.15$ $\times 10^{-4} \mu \mathrm{g} /$ cell $(n=4)$, which was not significantly different from the protein content of the cells exposed to serum-free DME only. In cells bathed in $20 \mathrm{mM} \mathrm{NH}_{4} \mathrm{Cl}+1 \mathrm{mM}$ amiloride the protein content increased significantly to $4.12 \pm 0.25$ $\times 10^{-4} \mu \mathrm{g} /$ cell $(n=5)$ (Fig. $12 ; 107 \pm 21 \%$ increase, $\left.P<0.001\right)$. These studies indicate that $(a)$ amiloride treatment does not alter basal cell protein content, and $(b)$ amiloride exposure does not inhibit the hypertrophic response induced by $\mathrm{NH}_{4} \mathrm{Cl}$. Further studies were performed to determine whether the $\mathrm{Na}^{+} / \mathrm{H}^{+}$antiporter in cells exposed to $1 \mathrm{mM}$ amiloride for $96 \mathrm{~h}$ remained inactivated since it seemed possible that the antiporter may have upregulated in cells chronically exposed to amiloride, thereby potentially overcoming its inhibitory effect. As depicted in Fig. 13, cells chronically exposed to amiloride (96 h) still failed to demonstrate antiport activity in the presence of amiloride ( $1 \mathrm{mM})$ after acute intracellular acidification using the $\mathrm{NH}_{4} \mathrm{Cl}$ prepulse technique (47). These results suggest that normal functioning $\mathrm{Na}^{+} / \mathrm{H}^{+}$antiport activity is not a necessary requirement for the hypertrophic response induced by exogenous $\mathrm{NH}_{4} \mathrm{Cl}$.

\section{Discussion}

Lotspeich and Halliburton first demonstrated that $\mathrm{NH}_{4} \mathrm{Cl}$ loading in the rat in vivo resulted in renal hypertrophy $(9,32$,
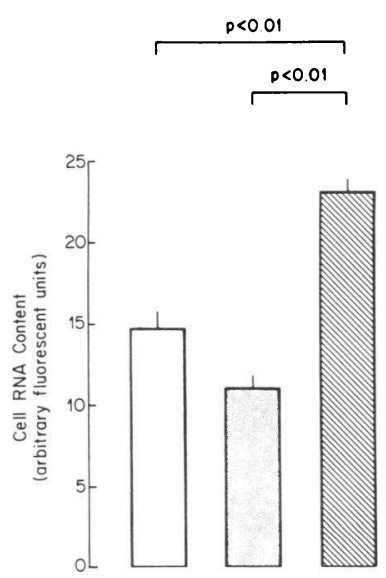

Figure 8. Effect of $\mathrm{NH}_{4} \mathrm{Cl}$ on JTC cell cytoplasmic RNA content $(72$ $\mathrm{h}$ exposure). JTC cells were exposed to serum-free DME (medium A) for $96 \mathrm{~h}$ and then to either serum-free DME (medium A), serum-free DME + $40 \mathrm{mM}$ mannitol (medium B), or serumfree DME + $20 \mathrm{mM} \mathrm{NH}_{4} \mathrm{Cl}$ (me$\operatorname{dium} \mathrm{C}$ ) for the next $72 \mathrm{~h}$. Cytoplasmic RNA content was significantly increased at $72 \mathrm{~h}$ exposure to $\mathrm{NH}_{4} \mathrm{Cl}$. Open bars, DME; stippled bars, DME + mannitol; hatched bars, $\mathrm{DME}+\mathrm{NH}_{4} \mathrm{Cl}$.
33). The increase in renal mass was associated with an increase in renal RNA content in the absence of an increase in DNA content, whereas ammonium citrate ingestion increased renal weight minimally and failed to alter RNA and DNA content. These results were interpreted as having demonstrated that acidosis per se caused the renal hypertrophy. In a recent study of cultured renal proximal tubule cells where the effect of changes in medium $\mathrm{pH}$ on cell growth were assessed in vitro, lowering the medium pH from 7.4 to 6.8 resulted in a hyperplastic response (increase in DNA synthesis as assessed by $\left[{ }^{3} \mathrm{H}\right]$ thymidine incorporation) (37). However, as mentioned, in vivo acidosis is associated with renal cell hypertrophy in the absence of an increase in DNA content. There are no reports of changes in medium $\mathrm{pH}$ resulting in hypertrophy of cells of renal or extrarenal origin. The results of the present study suggest the possibility that metabolic acidosis in vivo induces renal hypertrophy not as a result of the acidemia per se, but via an increase in renal ammoniagenesis. It is of interest that respiratory acidosis, which fails to stimulate renal ammoniagenesis to the same extent as metabolic acidosis (53), is associated with only minimal renal hypertrophy (54).

In the present study $2 \mathrm{mM} \mathrm{NH}_{4} \mathrm{Cl}$ was found to induce renal cell hypertrophy. Although the intracellular and peritubular capillary ammonia concentration has not yet been measured in vivo, the concentration of ammonia in the lumen of the rat proximal tubule in vivo has been measured in several micropuncture studies and varies from $\sim 0.4$ to $2.8 \mathrm{mM}(16$, 55-58). The ammonia concentration in the proximal tubule lumen increases to $\sim 1.3$ to $3.3 \mathrm{mM}$ in rats with metabolic acidosis (55-57), $\sim 5.6 \mathrm{mM}$ in rats with reduced renal mass (16), and $4.1 \mathrm{mM}$ in rats with potassium depletion (58). In the unstirred layer adjacent to the apical membrane the ammonia concentration may be greater. Therefore, the dose of $2 \mathrm{mM}$ $\mathrm{NH}_{4} \mathrm{Cl}$, which was found to induce hypertrophy in the present study, is within the physiologic range. In the inner medulla the concentration of ammonia is greater. The concentration of ammonia in rat papillary vasa recta blood is $\sim 2 \mathrm{mM}$ and increases to $6 \mathrm{mM}$ in metabolic acidosis (59). In the tubule lumen at the bend of Henle's loop and the tip of the collecting duct in the rat the ammonia concentration is 2.5 and $34 \mathrm{mM}$, respectively (59). During metabolic acidosis these values increase to 9.4 and $74 \mathrm{mM}$, respectively (59). It would be of interest to determine whether cells derived from tubules in the inner medulla that are exposed to higher concentrations of ammonia in vivo manifest less hypertrophy when exposed to $\mathrm{NH}_{4} \mathrm{Cl}(0-20 \mathrm{mM})$ than cells derived from cortical tubules (i.e., dose response is shifted to the right).

An increase in cell protein content can result from an increase in protein synthesis and/or a decrease in protein degradation. Most efforts to determine the cause of increased cell protein content in models of renal hypertrophy have focused on factors that modulate protein synthesis. In vivo renal hypertrophy resulting from either a reduction in renal mass or metabolic acidosis is associated with an increase in protein synthesis $(34,60)$. The rate of protein degradation has not been measured in these models or any other in vivo or in vitro model of renal hypertrophy. It is of interest that insulin, which has been reported to decrease the rate of protein degradation (61), causes rabbit proximal tubule cells to hypertrophy in vitro (62). The results of the present study provide the first evidence that in addition to an alteration in protein synthesis, a decrease in protein degradation may be an important mecha- 

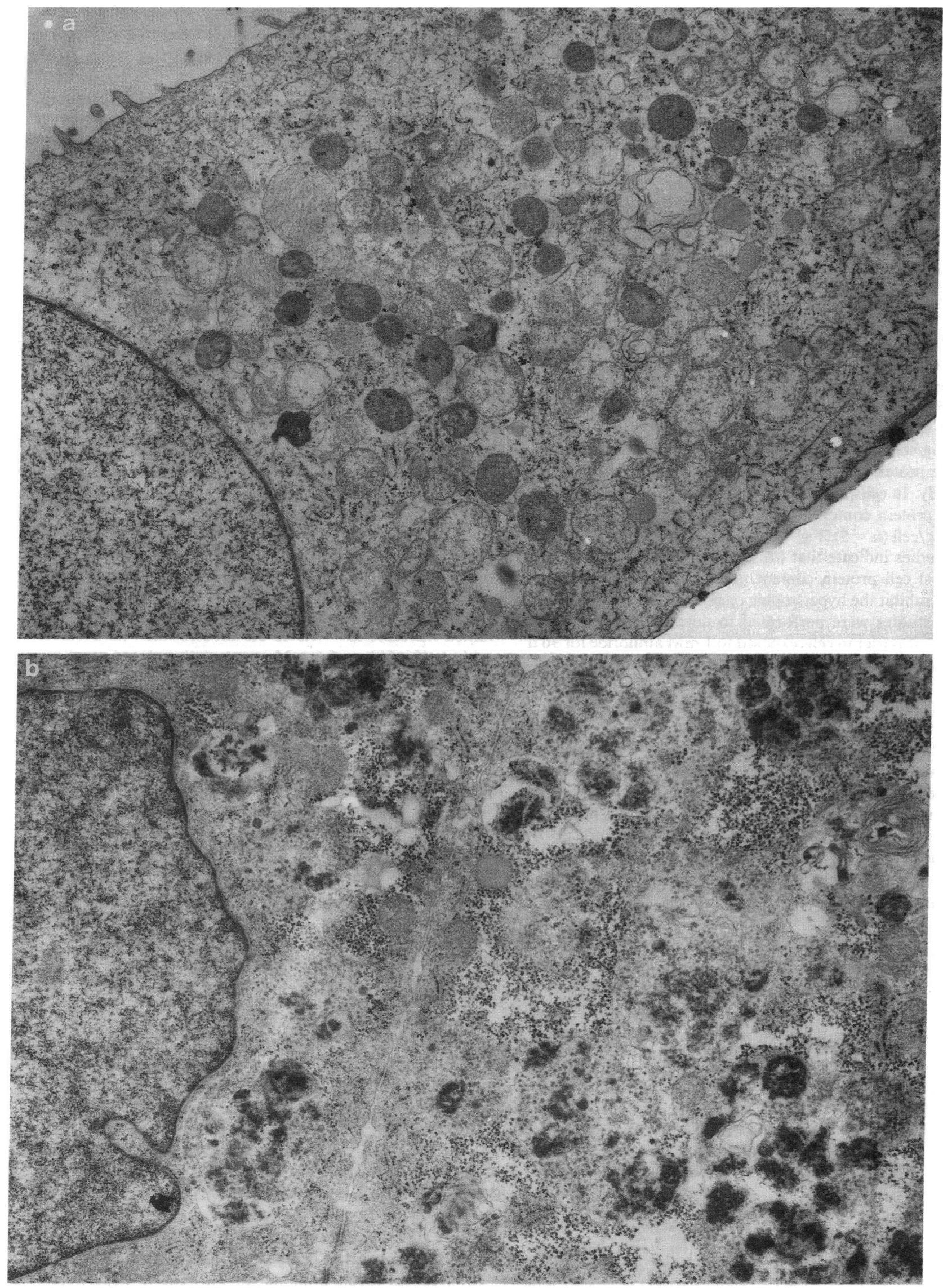

Figure 9. Electron micrograph of a JTC cell exposed for $96 \mathrm{~h}$ to serum-free DME (medium A) and then to either serum-free DME (medium A) (a) or serum-free DME $+10 \mathrm{mM} \mathrm{NH}_{4} \mathrm{Cl}\left(\right.$ b) for the following $96 \mathrm{~h}$. $\mathrm{NH}_{4} \mathrm{Cl}$ exposure results in a marked increase in ribosome number and lysosomal swelling. The lysosomes accumulate electron-dense material which is presently unidentified. $\times 10,000$. 


\begin{tabular}{|c|c|c|c|c|c|}
\hline & \multirow[b]{2}{*}{$n$} & \multicolumn{4}{|c|}{ Exposure time } \\
\hline & & $24 \mathrm{~h}$ & $48 \mathrm{~h}$ & $72 \mathrm{~h}$ & $96 \mathrm{~h}$ \\
\hline DME & 4 & $3.0 \pm 0.1$ & $2.6 \pm 0.1$ & $4.0 \pm 0.1$ & $3.4 \pm 0.35^{*}$ \\
\hline $\mathrm{DME}+$ mannitol $(40 \mathrm{mM})$ & 4 & $3.2 \pm 0.3$ & $3.0 \pm 0.1$ & $4.1 \pm 0.1$ & - \\
\hline $\mathrm{DME}+\mathrm{NH}_{4} \mathrm{Cl}(20 \mathrm{mM})$ & 4 & $2.1 \pm 0.1^{\ddagger \S}$ & $1.5 \pm 0.04^{\ddagger \S}$ & $2.1 \pm 0.1^{\ddagger \S}$ & $1.5 \pm 0.16^{\ddagger \|}$ \\
\hline
\end{tabular}

${ }^{*} n=6 ;{ }^{\ddagger} P<0.01 \mathrm{DME}+\mathrm{NH}_{4} \mathrm{Cl}(20 \mathrm{mM})$ vs. $\mathrm{DME} ;{ }^{\S} P<0.01 \mathrm{DME}+\mathrm{NH}_{4} \mathrm{Cl}(20 \mathrm{mM}) \mathrm{vs} . \mathrm{DME}+\operatorname{mannitol}(40 \mathrm{mM}) ; " ~ n=9$.

nism by which total cell protein content can increase in renal cells. The importance of modulating the rate of protein degradation has been well documented in models of liver growth such as liver regeneration, replacement of hemopoietic tissue by liver parenchymal tissue postnatally, and recovery from protein deprivation (63). In all these examples of liver growth a decrease in the rate of protein degradation is the most important cause of the increase in cell protein content. Several studies have documented the ability of weak bases, e.g., ammonia, methylalanine, and chloroquine, in nonrenal cells to elevate intralysosomal $\mathrm{pH}$, which prevents mannose-6-phosphatecoupled enzymes from being targeted to the lysosomes (52). It is probably via this mechanism that $\mathrm{NH}_{4} \mathrm{Cl}$ inhibits protein degradation in hepatocytes (25), rat fibroblasts (26), and mouse macrophages (27). These results complement the present finding that $\mathrm{NH}_{4} \mathrm{Cl}$ decreased the protein degradation rate and the cell content of the lysosomal enzymes cathepsin $\mathrm{L}$ and $B$ in JTC cells in a dose-dependent fashion. Whether the inhibition of lysosomal proteolysis can fully account for the decrease in protein degradation induced by $\mathrm{NH}_{4} \mathrm{Cl}$ requires further study. Since the concentration of ammonia increases axially from the cortex to the inner renal medulla, it might be expected that the lysosomal enzyme content of the nephron segments in the inner medulla would be markedly decreased. In addition, as has been demonstrated in cultured rat fibroblasts (26) and the present study, $\mathrm{NH}_{4} \mathrm{Cl}$ exposure causes lysosomal swelling, which has been attributed to the osmotic entry of $\mathrm{NH}_{4} \mathrm{Cl}$ (a weak base) into the acidic lysosomal compartment. Whether the lysosomes in tubule segments in the inner medulla are more swollen in vivo than more proximal nephron segments is unknown. In addition to lysosomes, the Golgi apparatus maintains a low internal $\mathrm{pH}$ which is important for the trafficking of proteins to their proper location in polarized cells. $\mathrm{NH}_{4} \mathrm{Cl}$ exposure by raising the internal $\mathrm{pH}$ in the Golgi apparatus inhibits these processes (64). It would be of

Table VI. Decrease in Protein Degradation Rate after $72 h$ Exposure to $\mathrm{NH}_{4} \mathrm{Cl}$

\begin{tabular}{rcc}
\hline $\mathrm{NH}_{4} \mathrm{Cl}$ & $n$ & Percent/cell per $3 \mathrm{~h}$ \\
\hline$m M$ & & \\
0 & 5 & $2.9 \pm 0.1$ \\
2 & 3 & $2.6 \pm 0.2$ \\
5 & 5 & $2.4 \pm 0.1$ \\
10 & 5 & $2.3 \pm 0.1$ \\
20 & 5 & $2.1 \pm 0.1$
\end{tabular}

interest to measure the lysosomal permeability to $\mathrm{NH}_{3} / \mathrm{NH}_{4}^{+}$, lysosomal enzyme content, lysosomal $\mathrm{pH}$, and $\mathrm{Golgi} \mathrm{pH}$ in tubules originating from the inner medulla to determine whether these nephron segments have somehow adapted to cope with the high concentration of ammonia to which they are exposed in vivo.

In addition to decreasing the protein degradation rate, exogenous $\mathrm{NH}_{4} \mathrm{Cl}$ exposure caused JTC cell protein content to increase as a result of increased protein synthesis. Ammonia has been reported to increase the rate of protein synthesis in sea urchin eggs (31) and differentiated astrocytes (23). Although the mechanism for $\mathrm{NH}_{4} \mathrm{Cl}$-induced increase in protein synthesis was not investigated in the present study, recent experiments in sea urchin eggs indicate that ammonia increases the rate of protein synthesis via a $\mathrm{pH}$-independent effect (31). Other amines such as tricaine and benzocaine which do not raise $\mathrm{pH}_{\mathrm{i}}$ were found to stimulate protein synthesis. In the present study the increase in protein synthesis was associated with an increase in total cell RNA content. An increase in protein synthesis and total RNA have been described in the in vivo models of hypertrophy associated with a reduction in renal mass and metabolic acidosis $(9,32-34,60)$. Protein degradation rates have not been assessed in these models of renal hypertrophy. It would be of interest to measure protein synthetic and degradation rates in various in vivo human models of renal hypertrophy in an attempt to classify these disorders into mechanisms of increase in protein content.

In the present study ammonia was added exogenously to proximal tubule cells. The question of whether an increase in endogenous ammonia production can also induce hypertrophy was not addressed. Endogenous ammonia production from glutamine in the proximal tubule, unlike exogenous ammonia addition, is associated with an increase in ATP production, bicarbonate production, possibly gluconeogenesis, and potentially an increase in $\mathrm{Na}^{+} / \mathrm{NH}_{4}^{+}$exchange $(65,66)$. In vivo,

Table VII. Effect of $\mathrm{NH}_{4} \mathrm{Cl}$ on Lysosomal Enzyme Activity (72 h Exposure)

\begin{tabular}{rccc}
\hline $\mathrm{NH}_{4} \mathrm{Cl}$ & $n$ & Cathepsin B activity & Cathepsin L activity \\
\hline$m M$ & & pmol/min per cell & pmol/min per cell \\
& & $0.51 \pm 0.001$ & $0.43 \pm 0.001$ \\
2 & 4 & $0.46 \pm 0.001$ & $0.39 \pm 0.001$ \\
5 & 5 & $0.37 \pm 0.001$ & $0.36 \pm 0.001$ \\
10 & 4 & $0.31 \pm 0.001$ & $0.22 \pm 0.001$ \\
20 & 5 & $0.28 \pm 0.001$ & $0.17 \pm 0.001$ \\
\hline
\end{tabular}




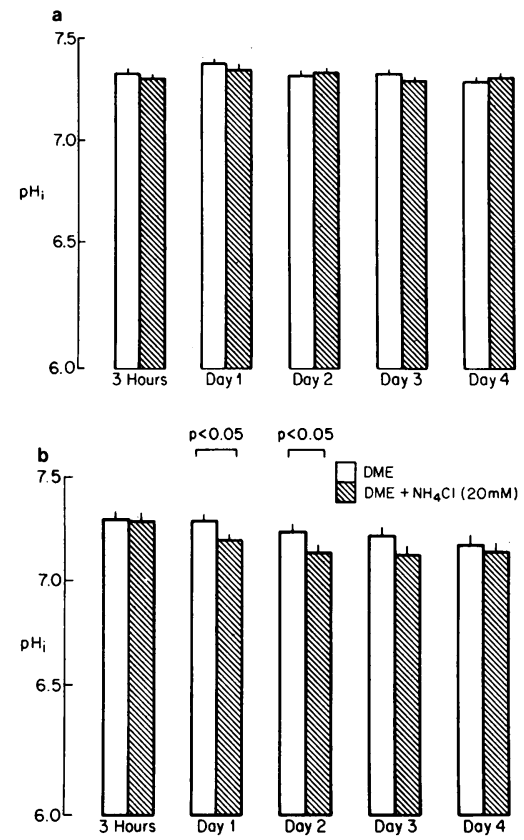
not significantly different from control at the remaining time points. The data represent the mean of at least three measurements. Each measurement was obtained from a separate cell monolayer.

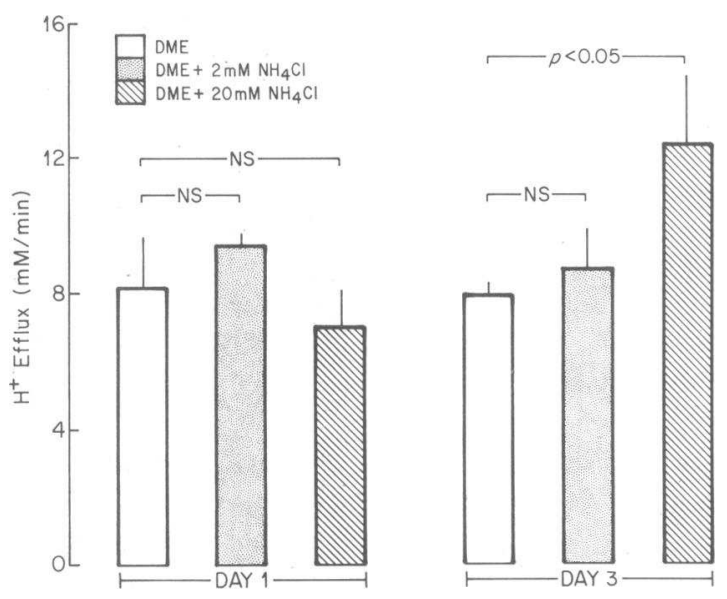

Figure 11. Effect of $\mathrm{NH}_{4} \mathrm{Cl}$ exposure on rate of $\mathrm{Na}^{+} / \mathrm{H}^{+}$exchange. JTC cells were bathed in serum-free DME (medium A) for $96 \mathrm{~h}$. The rate of $\mathrm{H}^{+}$efflux via the $\mathrm{Na}^{+} / \mathrm{H}^{+}$exchanger was measured in JTC cells exposed for an additional $24 \mathrm{~h}$ and $72 \mathrm{~h}$ exposure to either serum-free DME, serum-free DME $+2 \mathrm{mM} \mathrm{NH}_{4} \mathrm{Cl}$, or serum-free $\mathrm{DME}+20 \mathrm{mM} \mathrm{NH} \mathrm{N}_{4} \mathrm{Cl}$. To acid load the cells, on the day of study the monolayers were exposed to $20 \mathrm{mM} \mathrm{NH}_{4} \mathrm{Cl}$ in the absence of $\mathrm{Na}^{+}$(solution B) for $5 \mathrm{~min}$. After the removal of $\mathrm{NH}_{4} \mathrm{Cl}$ (solution $\mathrm{C}$ ), $\mathrm{pH}_{\mathrm{i}}$ decreased due to the rapid efflux of $\mathrm{NH}_{3}$. The cells were then exposed to $140 \mathrm{mM} \mathrm{NaCl}$ (solution $\mathrm{D}$ ). The amiloride-inhibitable, $\mathrm{Na}^{+}$-dependent rate of $\mathrm{pH}_{\mathrm{i}}$ recovery was measured $\left(d \mathrm{pH}_{\mathrm{i}} / d t\right)$ in the initial $45 \mathrm{~s}$. Cell buffer capacity $(\beta)$ was measured and $\mathrm{H}^{+}$efflux was calculated (see Methods). $2 \mathrm{mM} \mathrm{NH}_{4} \mathrm{Cl}$ did not alter the rate of $\mathrm{Na}^{+} / \mathrm{H}^{+}$activity after 24 or $72 \mathrm{~h}$ exposure. $20 \mathrm{mM} \mathrm{NH}_{4} \mathrm{Cl}$ significantly increased the rate of $\mathrm{Na}^{+} / \mathrm{H}^{+}$antiport activity after $72 \mathrm{~h}$ exposure. The results represent the mean of at least three measurements. Each measurement was obtained from a separate cell monolayer.

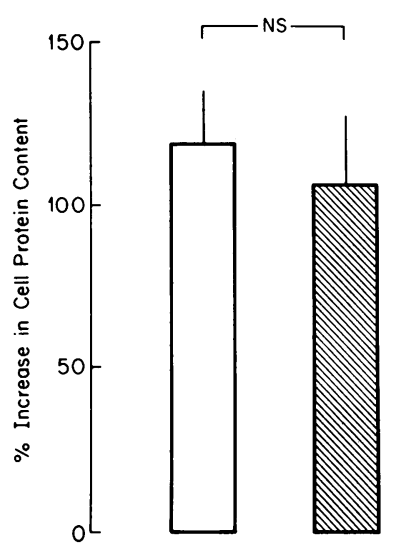

Figure 12. Lack of effect of inhibition of $\mathrm{Na}^{+} / \mathrm{H}^{+}$exchange on the $\mathrm{NH}_{4} \mathrm{Cl}$-induced hypertrophic response in JTC cells ( $96 \mathrm{~h}$ exposure). Increase in cell protein content was measured in JTC cells exposed initially to serum-free DME (medium $\mathrm{A}$ ) for $96 \mathrm{~h}$ and then for the following $96 \mathrm{~h}$ to either serum-free DME, serum-free $\mathrm{DME}+1 \mathrm{mM}$ amiloride, serumfree DME + $20 \mathrm{mM} \mathrm{NH}_{4} \mathrm{Cl}$ (medium $\mathrm{C}$ ) (open bars), or serumfree DME + $20 \mathrm{mM} \mathrm{NH}_{4} \mathrm{Cl}+1$ $\mathrm{mM}$ amiloride (hatched bars). Note that amiloride did not alter the hypertrophic response induced by $\mathrm{NH}_{4} \mathrm{Cl}$.

since the increase in the interstitial ammonia concentration in models of renal hypertrophy occurs primarily as a result of an increase in endogenous proximal tubule ammonia production, other segments of the nephron that also hypertrophy would be exposed to a higher concentration of ammonia exogenously. Further studies are required to assess the role of these factors in modifying the hypertrophic response.

Although the results of the present study indicate that $\mathrm{NH}_{4} \mathrm{Cl}$ can induce hypertrophy in vitro in the presence or absence of other serum growth factors, the results of studies by Griendling et al. suggest that $\mathrm{NH}_{4} \mathrm{Cl}$ may interact with growth factors to modulate the phosphoinositol pathway (67). In particular, these authors have reported that ammonia enhances the stimulation by angiotensin II of diacylglycerol formation in vascular smooth muscle cells. Recent studies of rats with renal hypertrophy secondary to a reduction of renal mass and type 1 diabetes mellitus have documented an increase in brush border protein kinase $C$ activity $(68,69)$. Further studies are required to determine whether exposure to ammonia \pm angiotensin II can increase protein kinase $\mathrm{C}$ activity in renal brush border vesicles.

Chronic hypokalemia has long been known to both increase renal ammonia production $(13,14)$ and induce renal hypertrophy (70). It was previously thought that hypokalemia causes intracellular acidosis which then stimulates ammonia production. That intracellular acidosis has been postulated to induce renal hypertrophy is in keeping with Lotspiech's hypothesis that extracellular acidosis causes renal hypertrophy. However, recent studies of proximal tubules derived from chronically $\mathrm{K}^{+}$-depleted rats suggest that $\mathrm{pH}_{\mathrm{i}}$ is not different from controls and yet these tubules produce more ammonia and glucose than control tubules (71). The mechanism by which a decrease in extracellular potassium modifies renal cell growth in vitro has been addressed. The results of these experiments indicate that an autocrine growth factor is released by BSC-1 cells when the extracellular $\mathrm{K}^{+}$concentration is reduced (72). Unlike the hypertrophic effect of ammonia on JTC cells and rabbit proximal tubule cells, the autocrine factor produced by BSC-1 cells appears to be mitogenic, making it less likely that ammonia plays an important role as a growth factor in this in vitro model of renal cell growth. In addition, the in vivo rat $\mathrm{K}^{+}$depletion model differs from the remnant kidney model in that in the former model: (a) morphologic changes mainly 

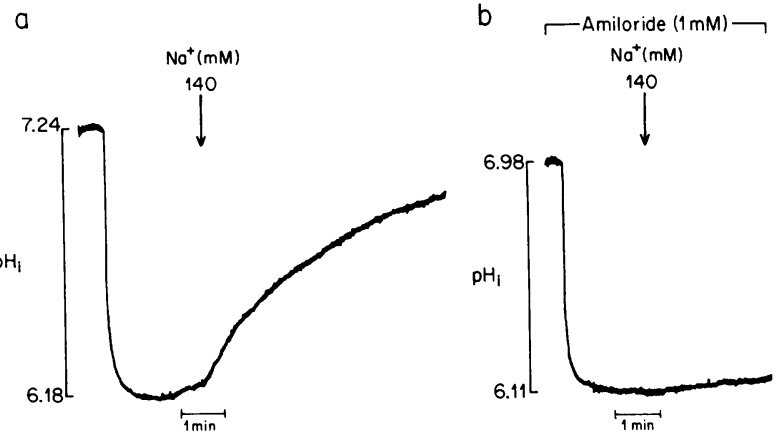

Figure 13. Effect of chronic amiloride exposure ( $96 \mathrm{~h}$ ) on JTC cell $\mathrm{Na}^{+} / \mathrm{H}^{+}$antiport activity. $\mathrm{Na}^{+} / \mathrm{H}^{+}$antiport activity was measured in cells exposed initially to serum-free DME (medium A) for $96 \mathrm{~h}$ and then to serum-free DME $+20 \mathrm{mM} \mathrm{NH}_{4} \mathrm{Cl}$ (medium $\mathrm{C}$ ) for the following $96 \mathrm{~h}$ in the absence $(a)$ or presence $(b)$ of $1 \mathrm{mM}$ amiloride. $\mathrm{pH}_{\mathrm{i}}$ was acutely acidified using the $\mathrm{NH}_{4} \mathrm{Cl}$ prepulse technique. After continuous exposure to $20 \mathrm{mM} \mathrm{NH}_{4} \mathrm{Cl}+1 \mathrm{mM}$ amiloride for $96 \mathrm{~h}$ the $\mathrm{Na}^{+} / \mathrm{H}^{+}$antiporter remained inactivated.

occur in the inner medulla, and $(b)$ hyperplastic changes are present (1). Although factors other than an increase in ammonia production are probably involved in the $\mathrm{K}^{+}$depletion model in vivo, of interest are the recent studies that have suggested that in the rat remnant kidney model and in the rat model of hypokalemic nephropathy, ammonia may cause interstitial nephritis by activation of the alternate complement pathway $(70,73)$. The authors found that administration of bicarbonate which decreased ammoniagenesis resulted in an amelioration of the histologic findings. In the chronic hypokalemic model of renal hypertrophy bicarbonate administration decreased the extent of renal hypertrophy despite the same degree of hypokalemia and more severe alkalemia (70). This latter finding complements the results of the present study in that bicarbonate administration according to the hypothesis presented in this report may have decreased the degree of renal hypertrophy via an inhibition of renal ammoniagenesis. It would be of interest to determine whether bicarbonate administration (or other maneuvers that would suppress ammoniagenesis) decreases the degree of renal hypertrophy in the remnant kidney model and other in vivo models of renal hypertrophy.

Several clinical models of renal hypertrophy (reduction in renal mass, type 1 diabetes mellitus, protein loading) are associated with an early increase in the single nephron glomerular filtration rate (SNGFR). The mechanism by which an increase in tubule flow rate could initiate renal hypertrophy is unknown. It has been suggested that an increase in SNGFR could induce renal hypertrophy by stimulating $\mathrm{Na}^{+}$transport, perhaps via the $\mathrm{Na}^{+} / \mathrm{H}^{+}$antiporter $(1,2)$. The results of the present study, in addition to the recent finding that L-triiodothyronine increases $\mathrm{Na}^{+} / \mathrm{H}^{+}$exchange activity in the absence of cell hypertrophy (74), suggest that elevated $\mathrm{Na}^{+} / \mathrm{H}^{+}$exchange activity demonstrated in several clinical models of hypertrophy may be a consequence rather than a cause of the hypertrophic response, and other mechanism(s) by which an increase in SNGFR could induce renal hypertrophy ought to be considered.

It has previously been demonstrated that an increase in SNGFR secondary to a reduction in renal mass is associated with an increase in the entry of ammonia into the proximal tubule lumen (16). Whole kidney ammonia production/glomerular filtration rate increases after a reduction in renal mass (15). In addition, the proximal tubule luminal ammonia concentration increases (16). In the isolated perfused mouse proximal tubule an increase in the luminal flow rate increases ammonia production (75). Given the rapidity by which ammonia production can be modulated by changes in proximal tubule flow, it seems possible that alterations in ammonia production could be the necessary link between a rise in SNGFR and subsequent renal hypertrophy.

Protein loading in the remnant kidney model results in a further increase in SNGFR, $\mathrm{Na}^{+} / \mathrm{H}^{+}$antiport activity, ammonia production/excretion, and increased renal hypertrophy (1, 2,10 ). Protein loading could stimulate renal ammonia production by $(a)$ increasing the flux of ammoniagenic precursors to the kidney, $(b)$ lowering systemic $\mathrm{pH}$, or $(c)$ increasing the proximal tubule luminal flow rate as a result of an increase in SNGFR. It remains to be determined whether, as in the hypokalemic model of renal hypertrophy, inhibition of ammonia production by bicarbonate administration can decrease the degree of renal hypertrophy in protein-loaded animals.

\section{Acknowledgments}

This work was supported by grants USHHS 5 RO1 DK25301 and DK39212 from the National Institutes of Health to Dr. Kurtz.

\section{References}

1. Fine, L. G. 1986. The biology of renal hypertrophy. Kidney Int. 29:619-634.

2. Harris, R. C., J. L. Seifter, and B. M. Brenner. 1984. Adaptation of $\mathrm{Na}^{+}-\mathrm{H}^{+}$exchange in renal microvillus membrane vesicles. Role of dietary protein and uninephrectomy. J. Clin. Invest. 74:1979-1987.

3. Cohn, D. E., K. A. Hruska, S. Klahn, and M. R. Hammerman. 1982. Increased $\mathrm{Na}^{+} / \mathrm{H}^{+}$exchange in brush border vesicles from dogs with renal failure. Am. J. Physiol. 243 (Renal Fluid Electrol. Physiol. 12):F293-F299.

4. Nord, E. P., A. Hafezi, J. D. Kaunitz, W. Trizna, and L. G. Fine. 1985. pH gradient-dependent increased $\mathrm{Na}^{+}-\mathrm{H}^{+}$antiport capacity of the rabbit remnant kidney. Am. J. Physiol. 249 (Renal Fluid Electrolyte Physiol. 18):F90-F98.

5. Kinsella, J., T. Cujdik, and B. Sacktor. $1984 . \mathrm{Na}^{+} / \mathrm{H}^{+}$exchange activity in renal brush border membrane vesicles in response to metabolic acidosis: the role of glucorticoid. Proc. Natl. Acad. Sci. USA. 81:630-634.

6. Tsai, C.-J., H. E. Ives, R. J. Alpern, V. J. Yee, D. G. Warnock, and F. C. Rector, Jr. 1984. Increased $V_{\max }$ for $\mathrm{Na}^{+} / \mathrm{H}^{+}$antiporter activity in proximal tubule brush border vesicles from rabbits with metabolic acidosis. Am. J. Physiol. (Renal Fluid Electrolyte Physiol. 16):F339-F343.

7. Seifter, J. L., and R. C. Harris. 1984. Chronic $\mathrm{K}^{+}$depletion increases $\mathrm{Na}^{+} / \mathrm{H}^{+}$exchange in rat renal cortical brush border membrane vesicles. Kidney Int. 24:302. (Abstr.)

8. Harris, R. C., B. M. Brenner, and J. L. Seifter. 1986. Sodiumhydrogen exchange and glucose transport in renal microvillus membrane vesicles from rats with diabetes mellitus. J. Clin. Invest. 77:724733.

9. Lotspeich, W. D. 1965. Renal hypertrophy in metabolic acidosis and its relation to ammonia excretion. Am. J. Physiol. 208:1138-1142.

10. Schoolwerth, A. C., R. S. Sandler, P. M. Hoffman, and S. Klahr. 1975. Effects of nephron reduction and dietary protein content on renal ammoniagenesis in the rat. Kidney Int. 7:397-404.

11. Sartorius, O., J. C. Roemmelt, and R. F. Pitts. 1949. The renal 
regulation of acid-base balance in man. IV. The nature of the renal compensation in $\mathrm{NH}_{4} \mathrm{Cl}$ acidosis. J. Clin. Invest. 28:423-439.

12. Good, D. W., and M. B. Burg. 1984. Ammonia production by individual segments of the rat nephron. J. Clin. Invest. 73:602-610.

13. Ching, S. T., T. M. Rojoff, and G. J. Gabuzda. 1973. Renal ammoniagenesis and tissue glutamine, glutamine synthetase and glutaminase 1 levels in potassium deficient rats. J. Lab. Clin. Med. 82:208-214.

14. Fraley, D. S., S. Adler, B. Rankin, N. Curthoys, and B. Zett. 1985. Relationship of phosphate-dependent glutaminase activity to ammonia excretion in potassium deficiency and acidosis. Miner. Electrolyte Metab. 11:140-149.

15. Maclean, A. J., and J. P. Hayslett. 1980. Adaptive change in ammonia excretion in renal insufficiency. Kidney Int. 17:595-606.

16. Buerkert, J., D. Martin, D. Trigg, and E. Simon. 1983. Effect of reduced renal mass on ammonium handling and net acid formation by the superficial and juxtamedullary nephron of the rat. Evidence for impaired reentrapment rather than decreased production of ammonium in the acidosis of uremia. J. Clin. Invest. 71:1661-1675.

17. Goldstein, L., J. M. Boylan, and H. Schröck. 1980. Adaptation of renal ammonia production in the diabetic ketoacidotic rat. Kidney Int. 17:57-65.

18. Vavatsi-Manos, O., and H. G. Preuss. 1976. The effects of high calcium concentrations on renal ammoniagenesis by rat kidney slices. Nephron. 17:474-482.

19. Jobin, J., C. M. Taylor, J. Caverzasio, and J. P. Bonjour. 1984. Calcium restriction and parathyroid hormone enhance renal compensatory growth. Am. J. Physiol. 246:F685-F690.

20. Knepper, M. A., and M. B. Burg. 1981. Increased fluid absorption and cell volume in isolated rabbit proximal straight tubules after in vivo DOCA administration. Am. J. Physiol. 241:F502-F508.

21. Hulter, H. N., J. F. Sigala, and A. Sebastian. 1978. $\mathrm{K}^{+}$deprivation potentiates the renal alkalosis-producing effect of mineralcorticoid. Am. J. Physiol. 235:F298-F309.

22. Gass, R. J. 1965. Renal and adrenal relationships in compensatory hyperplasia. Proc. Soc. Exp. Biol. Med. 118:342-346.

23. Hertz, L., Ch. R. K. Murthy, J. C. K. Lai, S. M. Fitzpatrick, and A. J. C. Cooper. 1987. Some metabolic effects of ammonia on astrocytes and neurons in primary cultures. Neurochem. Pathol. 6:97-129.

24. Helgeland, $\mathrm{K} .1981 . \mathrm{NH}_{4} \mathrm{Cl}$ and protein metabolism in human gingival fibroblasts. Scand. J. Dent. Res. 89:400-406.

25. Hopgood, M. F., M. Clark, and F. J. Ballard. 1977. Inhibition of protein degradation in isolated rat hepatocytes. Biochem. J. 164:399-407.

26. Poole, B., S. Ohkuma, and M. J. Warbarton. 1977. The accumulation of weakly basic substances in lysosomes and the inhibition of intracellular protein degradation. Acta Biol. Med. Ger. 36:1777-1788.

27. Dean, R. 1980. Protein degradation in cell cultures: general considerations on mechanisms and regulation. Fed. Proc. 39:15-19.

28. Shiokawa, K., Y. Kawazoe, H. Nomura, T. Miura, N. Nakakaru, T. Horiuchi, and K. Yamana. 1986. Ammonium ion as a possible regulator of the commencement of rRNA synthesis in Xenopus laevis embryogenesis. Dev. Biol. 115:380-391.

29. Schindler, J., and M. Sussman. 1979. Inhibition by ammonia of intracellular cyclic AMP accumulation in Dictyostelium discoideum: its significance for regulation of morphogenesis. Dev. Genet. 1:13-20.

30. Neave, N., A. Sobolowski, and G. Weeks. 1983. The effect of ammonia on stalk cell formation in submerged monolayers of Dictyostelium discoideum. Cell Differ. 13:301-307.

31. Dubé, F., and D. Epel. 1986. The relationship between intracellular $\mathrm{pH}$ and rate of protein synthesis in sea urchin eggs and the existence of an pH-independent event triggered by ammonia. Exp. Cell. Res. 162:191-204.

32. Lotspeich, W. D. 1967. Metabolic aspects of acid-base changes. Science (Wash. DC). 55:1066-1075.

33. Halliburton, I. W., and R. Y. Thompson. 1967. The effect of diet and unilateral nephrectomy on the composition of the kidney. Cancer Res. 27:1632-1638.
34. Haas, M., and D. P. Simpson. 1984. The effects of chronic metabolic acidosis on patterns of protein synthesis in rat renal cortex. Comp. Biochem. Physiol. 79B:187-194.

35. Van Thiel, D. H., J. S. Gavaler, J. M. Little, and R. Lester. 1977. Alcohol: its effect on the kidney. Metab. Clin. Exp. 26:857-866.

36. Eagle, H. 1973. The effect of environmental pH on the growth of normal and malignant cells. J. Cell. Physiol. 82:1-8.

37. Blumenthal, S., D. Lewland, M. Buday, N. Mandel, G. Mandel, and J. Kleinman. 1987. Separate roles of $\mathrm{pH}$ and $\mathrm{Na}^{+}$in hypertrophy and proliferation of renal tubule cells. Clin. Res. 35:543A. (Abstr.)

38. Sakhrani, L. M., B. Badie-Dezfooly, W. Trizna, N. Mikhail, A. G. Lowe, M. Taub, and L. G. Fine. 1984. Transport and metabolism of glucose by renal proximal tubular cells in primary culture. Am. J. Physiol. 246(Renal Fluid Electrolyte Physiol. 15):F757-F764.

39. Soon, D. C., N. Alavi, D. Livingston, S. Hiller, and M. Taub. 1982. Characterization of the primary rabbit kidney cultures that express proximal tubule functions in a hormonally defined medium. $J$. Cell Biol. 95:118-126.

40. Sedmark, J. J., and S. E. Grosberg. 1977. A rapid, sensitive and versatile assay for protein using Coomasie brilliant blue G250. Anal. Biochem. 79:544-560.

41. Crissman, H. A., P. F. Mullaney, and J. A. Steinkamp. 1975 Methods and applications of flow systems for analysis and sorting of mammalian cells. In Methods in Cell Biology. D. M. Prescott, editor. Academic Press, New York. 179-246.

42. Salzman, G. C., P. F. Mullaney, and B. Price. 1979. Light scattering approaches to cell characterization. In Flow Cytometry and Sorting. M. R. Melamed, P. F. Mullaney, and M. L. Mendelsohn, editors. John Wiley and Sons, New York. 105-124.

43. Gray, J. W., P. N. Dean, and M. L. Mendelsohn. 1979. Quantitative cell-cycle analysis. In Flow Cytometry and Sorting. M. R. Melamed, P. F. Mullaney, M. L. Mendelsohn, editors. John Wiley \& Sons, New York. 383-408.

44. Crissman, H. A., A. P. Stevenson, R. J. Kissane, and R. A. Tobey. 1979. Techniques for quantitative staining of cellular DNA for flow cytometric analysis. In Flow Cytometry and Sorting. M. R. Melamed, P. F. Mullaney, and M. L. Mendelsohn, editors. John Wiley \& Sons, New York. 243-262.

45. Barrett, A. J. 1980. Fluorimetric assays for cathepsin B and cathepsin $\mathbf{H}$ with methylcoumarylamide substrate. Biochem. J. 187:909-912.

46. Kurtz, I., and K. Golchini. 1987. $\mathrm{Na}^{+}$-independent $\mathrm{Cl}^{-}-\mathrm{HCO}_{3}^{-}$ exchange in Madin-Darby canine kidney cells: role in intracellular $\mathrm{pH}$ regulation. J. Biol. Chem. 262:4516-4520.

47. Roos, A., and W. F. Boron. 1981. Intracellular pH. Physiol. Rev. 61:296-434.

48. Dunnett, C. W. 1964. New tables for multiple comparisons with a control. Biometrics. 20:482-491.

49. Norman, J., B. Badie-Dezfooly, E. Nord, I. Kurtz, J. Schlosser A. Chaudhari, and L. G. Fine. 1987. EGF-induced mitogenesis in proximal tubular cells: potentiation by angiotensin II. Am. J. Physiol. 253(Renal Fluid Electrolyte Physiol. 22):F299-F309.

50. Golchini, K., and I. Kurtz. 1988 . $\mathrm{NH}_{3}$ permeation through the apical membrane of MDCK cells is via a lipid pathway. Am. J. Physiol. 255(Renal Fluid Electrolyte Physiol. 24):F135-F141.

51. Dubé, F., T. Schmidt, C. H. Johnson, and D. Epel. 1985. The hierarchy of requirements for an elevated intracellular $\mathrm{pH}$ during development of sea urchin embryos. Cell. 40:657-666.

52. Kornfeld, S. 1987. Trafficking of lysosomal enzymes. Fed. Proc. 1:462-468.

53. Rodriguez-Nichols, F., E. Laughrey, and R. L. Tannen. 1984. Response of renal $\mathrm{NH}_{3}$ production to chronic respiratory acidosis. $\mathrm{Am}$. J. Physiol. 247(Renal Fluid Electrolyte Physiol. 16):F896-F903.

54. Zeidel, M., and J. L. Seifter. 1988. Regulation of $\mathrm{Na}^{+} / \mathrm{H}^{+}$exchange in renal microvillus vesicles in chronic hypercapnia. Kidney Int. 34:60-66.

55. Sajo, I. M., M. B. Goldstein, H. Sonnenberg, B. J. Stinebaugh, D. R. Wilson, and M. L. Halperin. 1981. Sites of ammonia addition to 
tubular fluid in rats with chronic metabolic acidosis. Kidney Int. 20:353-358.

56. Good, D. W., and T. D. Dubose, Jr. 1987. Ammonia transport by early and late proximal convoluted tubule of the rat. J. Clin. Invest. 79:684-691.

57. Simon, E., D. Martin, and J. Buerkert. 1985. Contribution of individual superficial nephron segments to ammonium handling in chronic acidosis in the rat. Evidence for ammonia disequilibrium in the renal cortex. J. Clin. Invest. 76:855-864.

58. Jaeger, P., B. Karlmark, and G. Giebisch. 1983. Ammonium transport in rat cortical tubule relationship to potassium metabolism. Am. J. Physiol. 245(Renal Fluid Electrolyte Physiol. 14):F593-F600.

59. Good, D. W., C. R. Caflisch, and T. D. Dubose, Jr. 1987. Transepithelial ammonia concentration gradients in inner medulla of the rat. Am. J. Physiol. 252(Renal Fluid Electrolyte Physiol. 21):F491-F500.

60. Coe, F., and P. R. Korty. 1967. Protein synthesis during compensatory renal hypertrophy. Am. J. Physiol. 213:1585-1592.

61. Long, W. M., B. H. L. Chua, B. L. Munger, and H. E. Morgan. 1984. Effects of insulin on cardiac lysosomes and protein degradation. Fed. Proc. 43:1295-1300.

62. Fine, L. G., B. Badie-Dezfooly, A. G. Lowe, A. Hamzeh, J. Wells, and S. Salehmoghaddam. 1985. Stimulation of $\mathrm{Na}^{+} / \mathrm{H}^{+}$antiport is an early event in hypertrophy of renal proximal tubule cells. Proc. Natl. Acad. Sci. USA. 82:1736-1740.

63. Scornick, $O$. A. Role of protein degradation in the regulation of cellular protein content and amino acid pools. Fed. Proc. 43:12831288.

64. Caplan, M. J., J. L. Stow, A. P. Newman, J. Madri, H. C. Anderson, M. G. Farquhar, G. E. Palade, and J. D. Jamieson. 1987. Dependence on $\mathrm{pH}$ of polarized sorting of secreted proteins. Nature (Lond.). 329:632-635.

65. Halperin, M. L., M. B. Goldstein, B. J. Stinebaugh, and R. L.
Jungas. 1985. Biochemistry and physiology of ammonium excretion. In The Kidney: Physiology and Pathophysiology. D. W. Seldin and G. Giebisch, editors. Raven Press, New York. 1471-1490.

66. Kinsella, J. L., and P. S. Aronson. 1981. Interaction of $\mathrm{NH}_{4}^{+}$ and $\mathrm{Li}^{+}$with the renal microvillus membrane $\mathrm{Na}^{+} / \mathrm{H}^{+}$exchanger. $A m$. J. Physiol. 241(Cell Physiol. 10):C220-C226.

67. Griendling, K. K., B. C. Berk, and R. W. Alexander. 1988. Evidence that $\mathrm{Na}^{+} / \mathrm{H}^{+}$exchange regulates angiotensin II-stimulated diacylglycerol accumulation in vascular smooth muscle cells. J. Biol. Chem. 263:10620-10624.

68. Hise, M. K. 1987. Regulation of calcium/lipid dependent protein kinase (PKC) following nephron loss. Kidney Int. 31:399. (Abstr.)

69. Mehta, P. S., and M. K. Hise. 1988. Regulation of calcium/ phospholipid protein kinase $\mathrm{C}$ (PKC) during diabetic renal growth. Kidney Int. 33:393. (Abstr.)

70. Tollins, J. P., M. K. Hostetter, and T. H. Hostetter. 1987. Hypokalemic nephropathy in the rat. Role of ammonia in chronic tubular injury. J. Clin. Invest. 79:1447-1458.

71. Schoolwerth, A. C. 1988. Measurement of intracellular pH in suspension of renal cortical tubules from potassium depleted rats. Kidney Int. 33:394. (Abstr.)

72. Walsh-Reitz, M. M., and F. G. Toback. 1984. Growth of kidney epithelial cells in culture: evidence for autocrine control. Am. J. Physiol. 256:C350-C354.

73. Nath, K. A., M. K. Hostetter, and T. H. Hostetter. 1985. Pathophysiology of chronic tubulo-interstitial disease in rats. Interactions of dietary acid load, ammonia, and complement component C3. J. Clin. Invest. 76:667-675.

74. Yonemura, K., L. Cheng, and B. Sacktor. 1988. Effect of Ltriiodo-thyronine $\left(\mathrm{T}_{3}\right)$ on $\mathrm{Na}^{+}-\mathrm{H}^{+}$exchange activity in cultured opposum kidney (OK) cells. Kidney Int. 33:177. (Abstr.)

75. Nagami, G. T., and K. Kurokawa. 1985. Regulation of ammonia production by mouse proximal tubules perfused in vitro. Effect of luminal perfusion. J. Clin. Invest. 75:844-849. 